\title{
DOI: https://doi.org/10.24297/jac.v17i.8537
}

\section{Improving Quality of Water from Murchison Bay using Clay from Chelel, Kapchorwa District, Uganda}

\author{
Mukasa-Tebandeke, I. Z1; *Karume, I²; Wasajja, H. Z3; Nankinga. R ${ }^{3}$ \\ ${ }^{1}$ Department of Chemistry, Faculty of Science Kabale University, Uganda \\ ${ }^{2}$ Chemistry Department, School of Physical Sciences, College of Natural Sciences, Makerere University \\ ${ }^{3}$ Departments of Earth Sciences, Wesleyan University, Connecticut USA.
}

ishamukasa@cns.mak.ac.ug

\begin{abstract}
Pollution resulting from increased human activities is threatening Lake Victoria, its effects are characterized by eutrophication, high turbidity, $\mathrm{pH}$, iron(II) concentration and chemical oxygen demand (COD). In this study we have investigated the effect of Fe-montmorillonite clay from Chelel on turbidity, $\mathrm{pH}$, concentration of iron, total suspended soils, total nutrients and COD of water sampled from Murchison bay watershed of Nakivubo channel south of Kampala. Varying amounts of clay powder was vigorously stirred with water samples for 5 minutes, filtered using Whitman paper at ambient temperatures. The optimum concentration of clay of $0.4 \mathrm{gl}^{-1}$ was found to produce $73.5 \pm 2 \%$ fall in COD indicating elimination of microbes and organic waste. The $\mathrm{pH}$ of water became $6.3 \pm 0.2$ showing that impurities had been bound to clay. The turbidity of filtrate dropped to $15.7 \pm$ 0.3 NTUshowing that clarity of water was improved by adsorption of suspended solids to clay minerals. The concentration of iron(II) fell from $3.7 \pm 0.3$ to $2.5 \pm 0.2 \mathrm{mgl}^{-1}$ indicating fairly high extent of heavy metal removal from Murchison bay (MB) waters. The TSS and nutrients in MB water also decreased greatly when clay was stirred with water at ambient temperatures. The available data can be relied on to recommend use of this clay in treatment of waste water and/or sewage from Kampala. Further studies on combined use of clays with alums, zeolites and/or lime need to be carried out.
\end{abstract}

\section{Introduction}

Water is the most precious resource on Earth. For the vast quantity of life to exist, access to fresh water is important. Although the water constitutes more than $70 \%$ of the Earth surface, only $2.5 \%$ of it is fresh. So protecting fresh water reserves around the world is very important. Sources of fresh water are easily contaminated to become undrinkable through pollution but the effects can be reversed through wastewater treatment (Syafalni et al. 2013). Man's inventions and advancements, have come with pollution problems facing lakes, oceans and rivers; and the pollution problems can only be amended after exploring how they arose using naturally occurring materials (Jiang et al, 2006). Surface water pollution is the most visible form of water pollution where in plastics and garbage can be seen floating in lakes, rivers and oceans as was reported about river Lubigi (Musingizi et al. 2013). Surface water pollution may include industrial accidents like oil spills and wastewater. Ground water pollution happens beneath the soil and is caused by highly toxic chemicals like pesticides or chemical spills. Depletion of oxygen in water is caused by microorganisms present in polluted water that consume biodegradable wastes (Syafalni et al. 2013).

A watershed is land that water flows across or through on its way to a common stream, lake or river. It can be a drainage basin or an area where all water flowing in goes to a common outlet like the estuary or reservoir. It consists of all surface as well as underground water and aquifers. Watersheds affect the quality of drinking and recreation water. Algae blooms from fertilizer runoff during rain harm the watershed health; but nutrients can 
be got rid of by using clays (Bellir, 2013). Unhealthy watersheds affect wildlife, is harmful to man, affects aquatic life, offsets changes in the ecosystems. It was further reported that heavy metals readily adsorb on clay particles thus alleviating pollution (Aljil and Fares, 2014, Aljlil et al. 2011 Fresh water ecosystems are linked to watersheds tightly but this is influenced by man (EPA). Watershed management unveils means to eliminate nutrients from water yet fish farming introduces fertilizers and nutrients for the rapid growth of fish. Addition of fertilizers promotes growth of aquatic weeds and algae; yet addition of clay to polluted water removed biological, organic and inorganic contaminants (Srinvasan, 2011). Elimination of algae and weeds necessitates use of algaecides and herbicides, yet upon death, weeds and algae lie on bottom rot, releasing bound phosphorous and nitrogen back to water and creating anaerobic conditions at bottom of water mass. Lack of oxygen at base causes massive release of nitrogen and phosphorous from sediments and lowers quality of fresh water body. With more nitrogen and phosphorous in water, more algae and weeds grow abundantly and more poison is introduced. Herbicides and algaecides wreck the quality of water. Natural processes oxygenate water bodies to bind nitrogen and phosphorous to sediments at bottom of water mass and improve its quality. It was shown that clay adsorbents if stirred with polluted water flocculates nutrients, organic and inorganic pollutants (Kennedy et al. 2018).

As microorganism proliferate, toxins like ammonia increase. Nutrients pollution is brought about by presence of fertilizers and wastes allow algae and weeds to thrive thus hurting marine life (Jiang et al. 2006). Chemical pollution may result from plastics, home care and personal care products entering aquatic ecosystems. Phthalates present in plastics and cleaning agents are responsible for the flexibility of plastics and scents of soaps and air fresheners; and when disposed can contaminate water supplies and caused healthy problems. It was reported that organic pollutants readily adsorb on clay particles (Zadaka et al. 2008); in much the same way as inorganic pollutants adsorb on bentonite ((Barbooti, et al. 2015) relieving pollution. Lake Victoria is Africa's largest freshwater resource covering about $68,800 \mathrm{~km}^{2}$, shared between Uganda, Kenya and Tanzania. Its shoreline is composed of gulfs and bays that receive municipal and industrial wastes from adjacent urban centers. Murchison Bay is located at north-western part of Lake Victoria is affected by flooding and pollution (Hecky et al. 2010; Scheren et al. 2000). The pollutant loading in the Murchison bay, MB from streams has increased due to population growth, wetland encroachment, industrialization and paving of urban centers have led to flooding in the watershed. Increased agricultural practices around near rivers draining in MB have led to increased sediment and nutrient loading in the watershed and consequently to the lake through non-point source pollution (Machiwa, 2003). Non-point pollution from catchments around MB was reported to be higher than that from point sources without quantification (Banadda et al. 2009). A comparison of the existing phosphorus, $\mathrm{P}$ in municipal and water runoff from agricultural fields revealed a $55 \%$ of the total $\mathrm{P}$ input to Lake Victoria (Tamatamah et al. 2005). Persistent outbreak of algal blooms in the MB and increased mass occurrences of cyanobacteria was reported to be caused by increased nutrient pollution (Cózar et al. 2007; Haande et al. 2011). The quality of water in MB was shown to be influenced by nutrients loading in runoff from the catchment and population centers upstream (Cózar et al. 2007; Bracchini et al. 2007). MB is heavily eutrophic, and nitrogen, $\mathrm{N}$ was reported to be the limiting nutrient (Haande et al. 2011; Ssebiyonga et al. 2013).

It was reported that when waters of the lake flow towards the gulf or bay and the reverse, the mixing that occurs results in nutrient recycling and water quality is lowered (Gikuma-Njuru and Hecky, 2005). It was observed that the Winam or Nyanza Gulf (Kenya) in the north eastern part of Lake Victoria provided a net source of dissolved silica and total $\mathrm{N}$ and $\mathrm{P}$ to the gulf depending on the interchange through the Rusinga Channel (Gikuma-Njuru and Hecky, 2005). The quality of water quality in the MB on shores of Lake Victoria was reported to be affected by pollution, river inflows, wetland management and flora and fauna populations (Akurut et al. 2017, 2014). The quality of water deteriorated exponentially in the period 2001-2014 due to increased pollution and the high residence time of water. The worst water quality was in 2010 when diffuse pollution intensified due to the lining of more drainage channels within Kampala City in addition to the declining wetland effect (Akurut et al. 2017). 
As water runs over and through the watershed, it picks and carries contaminants and soil. If untreated, pollutants wash directly to water ways. The contaminants may infiltrate the ground water, and concentrate in streams and rivers wherefrom they are carried to watersheds and lakes. Agricultural practices in the hinterland to MB greatly affect the purity of water in the bay but could be reversed through exposure of the water to clay minerals (Singh et al. 2018). Industries may generate wastewater containing high concentration of greases or oils, heavy metal ions, volatile organic compounds or nutrients like ammonia and phosphates and shall require special treatment before discharge to the environment. Such treatment requires use of clay to adsorb nutrients and photodecompose algae (Kennedy et al. 2018). Commercial fertilizers, manure or sludge introduces nutrients in water, but nutrients may also enter a water mass through runoff from crop residues, irrigation water or wildlife. Farms with large livestock and poultry operations may pollute the environment through littering. Water flowing to streams picks dirt along the way and gets polluted.

Potable water treatment uses chlorine, fluorine and alums which are believed to be poisonous or ozone a natural ingredient in air. Chlorine kills bacteria, but to keep chlorine in active, it is ammoniated producing a carcinogenic chemical. Fluorine addition to water is thought to cause osteoporosis, brittle bones and teeth and cancer. Yet aluminium sulphate, poly aluminium chloride, alums added to remove suspended solids in water introduce impurities like epichlodine which is carcinogenic. Aluminium is poisoning factor in encephalopathy, may cause Alzheimer's disease (Yarahmadi et al. 2009).

In this study we investigated the clarification of water from MB using Fe-montmorillonite clay from Chelel to alleviate use of alums, chlorine and/or fluorine poisons because the use of clays is becoming popular as adsorbent and ion-exchange for water and wastewater treatment in removing heavy metals, organic and inorganic pollutants (Abdallah and Gaber, 2004).

The development of urban centers in Kampala involved removing plants, changing surface topography and altering natural water drainage networks. This affected the MB watershed. In addition, manmade land covers like tarmacked roads and buildings act as fast lanes for rain water. Rain water which would be absorbed by soil and plants is sent directly to streams and rivers, thus increasing chances of flooding of MB because more water pools form in the area than would reach if nature was still restricting its flow. By far the leading source of pollution in the bay is polluted rain water runoff as shown in Figure 1 (EPA) but it could be overcome by damming and treating collected water with clay powder before being released to rivers or lakes (Ali et al. 2014).
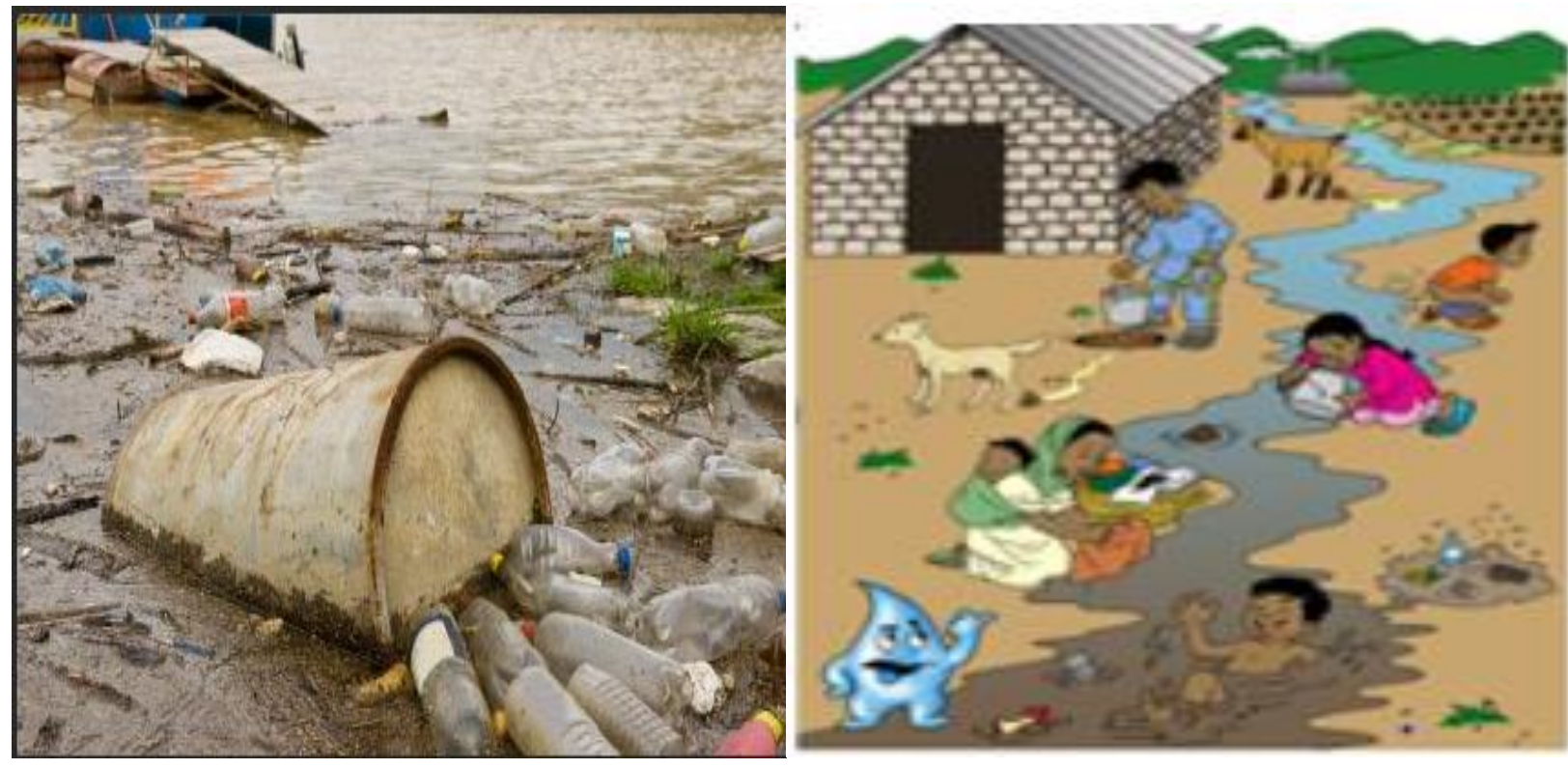


\section{Figure 1: Pollution of water in pictures}

The quality characteristics of fresh water resources vary depending on the extent of pollution and the duration the water takes to reach a common collecting basin or lake. Parameters like chemical oxygen demand (COD), color, $\mathrm{pH}$, iron content, nutrients content, total suspended solids, turbidity and others are often used to describe the level of water contamination. The same parameters may be used to show the extent to which pollution has be overcome if they are measured on water that has been purified. COD indicates the amount of oxygen required to oxidize all soluble and particulate organic and inorganic substances in water under specific conditions. The organic matter present in water is oxidized by potassium dichromate (VI) in presence of sulfuric acid silver sulfate and mercury (II) sulfate to produce carbon dioxide and water. The quantity of potassium dichromate (VI) used is calculate by the difference in volumes of ammonium iron (II) sulfate consumed in blank and sample titrations. COD test is commonly used to indirectly measure the amount of oxidizable organic and inorganic compounds in water. If the COD is high, the amount of pollution in the test sample is high. Biochemical oxygen demand, BOD is a measure of, the amount of oxygen that require for the bacteria to degrade the organic components present in water and wastewater. In most situations, COD is by far higher than BOD for polluted waters (Lenore et al. 2005).

Turbidity is a physical expression of pollution referring to the cloudiness or haziness of a fluid caused by suspended solids that are usually invisible to the naked eye. Turbidity is the measure of visible material in suspension in a liquid. Turbidity of water may be caused by silt, clay, algae or other organisms when present in large numbers. The amount and character of turbidity depends on type of soil over which water flows and the velocity of flowing water. The method used to determine turbidity is based on a comparison of the intensity of light scattered by the sample in specific conditions with the intensity of light scattered by standard reference suspension under the same condition. The higher the intensity of scattered lights, higher the turbidity. Formazine polymer has gained acceptance as the turbidity standard reference suspension for water because it is easy to prepare and is more reproducible in its lights scattering properties than the clay and other turbid natural water standards used. The turbidity of a given concentration of formazine has an approximate turbidity of 100 NTU, when measured on candle turbidity meter

Solids in water refer to matter suspended or dissolved in water or wastewater. Determination of solids in water is very important in assessing the suitability of water used for drinking and industrial purposes. The solid analysis in water can be characterized in many ways such as total solids, suspended solids, dissolved solids fixed solids, volatile solids and settleable solids. The total solids refer to the material left in the vessel after evaporation of a sample of wastewater and its subsequent drying in an oven at a definite temperature. Water that are low in organic matter and total mineral content and are intended for human consumption may be examined under $103-105^{\circ} \mathrm{C}$ or $179-181^{\circ} \mathrm{C}$.

With more nutrients generated and being introduced into the environment, concern about nutrients' effect on the freshwater environment has risen. While nutrients such as nitrogen and phosphorus are naturally present in the environment, and are important for maintaining a balanced aquatic ecosystem, human activities increase their level and, as a result, contribute to the eutrophication process. Eutrophication is caused by an increase in nutrients, which increase algal bloom, so total phosphate and nitrate content of a water mass implies determination of biological extent of pollution. Colorimetric detection is used by measuring nitrates at an absorbance of $220 \mathrm{~nm}$. Expected nitrate level in freshwater is usually found in the range of 0.1 to $4 \mathrm{mg} / \mathrm{L}$. Unpolluted waters generally have nitrate levels below $1 \mathrm{mg} / \mathrm{L}$. The effluent of some sewage treatment plants may have caused rise to levels in excess of $20 \mathrm{mg} / \mathrm{L}$. Levels of nitrate above $10 \mathrm{mg} / \mathrm{L}$ in drinking water can cause a potentially fatal disease in infants called methemoglobinemia, or Blue-Baby Syndrome.

The total phosphorus is explicit measure of orthophosphate, condensed phosphate, and organic phosphate which are forms of nutrient pollution. This is done by first digesting the sample to convert all the other forms to 
orthophosphate. The ascorbic acid method determines all phosphate as the sample is not filtered. Complete oxidation of the total phosphorus in the sample can be achieved. At near-boiling water temperature, the oxidation is performed to ensure complete oxidation of the dissolved and particulate phosphates. Phosphate ions are converted to a phosphomolybdate complex using sulfuric acid ammonium molybdate. The phosphomolybdate is then reduced, using ascorbic acid, to molybdenum blue. Using colorimetric detection, the intensity of the blue color is detected at $880 \mathrm{~nm}$ and is proportional to the phosphate concentration in the sample. Spectrophotometric methods are based on the formation of yellow molybdophosphoric acid and its reduction to a blue heteropoly compound, phosphomolybdenum blue (Standard Methods, 1998; Lyddy-Meaney et al. 2002; Zhang and Chi, 2002).

Water pollution occurs when harmful substances often chemicals or microorganisms contaminate a stream, river, lake, ocean, aquifer, or other body of water, degrading water quality and rendering it toxic to humans or the environment. Water is vulnerable to pollution because it is universal solvent, so it dissolves more substances than any other liquid. This is why water is so easily polluted. Toxic substances from farms, town, and factories readily dissolve into and mix with it, causing water pollution.

Phosphorus and nitrogen are essential nutrients for the plants and animals that make up the aquatic food web. Since phosphorus is the nutrient in short supply in most fresh waters, even a modest increase in phosphorus can cause accelerated plant growth, algae blooms, low dissolved oxygen, and the death of certain fish, invertebrates, and other aquatic animals.

The research estimating the levels of phosphates and sulfates in three selected springs in Baraton Location, in the Nandi County, Rift valley province in Kenya showed the phosphates concentration ranged from $2.79 \mathrm{mg} / \mathrm{L}$ to $622 \mathrm{mg} / \mathrm{L}$, while sulfates ranged from $109.8 \mathrm{mg} / \mathrm{L}$ to $250.98 \mathrm{mg} / \mathrm{L}$ (Swammy et al. 2013). The source of phosphates was artificial or anthropogenic depending on the activities occurring in the area under study (American Public Health Association, 1999). The use of phosphate based detergents has impacted on the water quality by introducing excess nutrients to the water. Accelerated eutrophication may occur as a result of the phosphorus content of detergents in natural waters (Egemen, 2000). The combined effects of excessive concentrations of detergents in natural waters may reduce oxygen concentrations, change color of water, increase turbidity and sedimentation, and decrease in biological activity. In developing countries, discharges from point sources have increased as a result of industrialization and high living standards. Additionally, excessive nutrient loads to rivers reulted untreated wastewater discharges (Smith et al. 1999). The phosphate ions in natural water causes most serious environmental pollution because of its contribution to the eutrophication process (Ansari et al. 2010). The presence of phosphates in water bodies is of international concern due to its effects on water quality. The threshold value of phosphate for drinking water is $0.1 \mathrm{mg} / \mathrm{L}$ (Razman et al. 1999).

Rivers contain approximately $0.5-1 \mathrm{ppm}$ of iron, and groundwater contains $100 \mathrm{ppm}$. Drinking water may not contain more than 200 ppb of iron. Most algae contain between 20 and 200 ppm of iron, and some brown algae may accumulate up to $4000 \mathrm{ppm}$. Dissolved iron is mainly present as aqueous $\mathrm{Fe}(\mathrm{OH})_{2}{ }^{+}$under acidic and neutral, oxygen-rich conditions. Under oxygen-poor conditions it mainly occurs as binary iron. Iron is part of many organic and inorganic chelation complexes that are generally water soluble iron does not clearly alter in pure water or in dry air, but when both water and oxygen are present, iron corrodes. Its silvery color changes to a reddish-brown, because hydrated oxides are formed. Dissolved electrolytes accelerate the reaction mechanism, which is as follows:

$4 \mathrm{Fe}+3 \mathrm{O}_{2}+6 \mathrm{H}_{2} \mathrm{O} \longrightarrow 4 \mathrm{Fe}^{3+}+12 \mathrm{OH}$ 
$4 \mathrm{Fe}^{3+}+12 \mathrm{OH}^{-} \longrightarrow$

$4 \mathrm{Fe}(\mathrm{OH})_{3}$ or $4 \mathrm{FeO}(\mathrm{OH})+4 \mathrm{H}_{2} \mathrm{O}$

Usually the oxide layer does not protect iron from further corrosion, but is removed so more metal oxides can be formed. Electrolytes are mostly iron (II) sulfate, which forms during corrosion by atmospheric $\mathrm{SO}_{2}$. Naturally occurring iron oxide, iron hydroxide, iron carbide and iron penta-carbonyl are water insoluble. The water solubility of some iron compounds increases at lower $\mathrm{pH}$ values. Microorganisms release iron siderochrome, which can be directly taken up by plants. Iron in young children negatively affects mental development, impairs irritability, and causes concentration disorder. Young children, pregnant women and women in their period are often treated with iron (II) salts upon iron deficits. Iron present in water can be used as basis to study pollution.

Classification of clay minerals in the literature has four groups: kaolinite group, illite group, smectite group, and vermiculite. Kaolinite is a clay mineral, with the chemical composition $\mathrm{Al}_{2} \mathrm{Si}_{2} \mathrm{O}_{5}(\mathrm{OH})_{4}$ or $\mathrm{Al}_{2} \mathrm{O}_{3} \cdot 2 \mathrm{SiO}_{2} \cdot 2 \mathrm{H}_{2} \mathrm{O}(\mathrm{Kerr}$, 1952). Illite is a group of micas of the igneous and metamorphic rocks. They have a unit layer composed of octahedral sheets sandwiched between tetrahedral sheets. Illite is a phyllosilicate or layered alumino-silicate. Its structure is constituted by the repetition of tetrahedron - octahedron - tetrahedron layers. The chemical formula is given as $\left(\mathrm{K}_{1} \mathrm{H}_{3} \mathrm{O}\right)(\mathrm{Al}, \mathrm{Mg}, \mathrm{Fe})_{2}(\mathrm{Si}, \mathrm{Al})_{4} \mathrm{O}_{10}\left[(\mathrm{OH})_{2}\left(\mathrm{H}_{2} \mathrm{O}\right)\right]$ but there is considerable ion substitution. It occurs as aggregates of small monoclinic grey to white crystals (Gates, 2002). Montmorillonites consist of an alumina octahedral sheet between two silica tetrahedral sheets. These sheets are bound loosely, making it relatively unstable. The attracted water molecules easily insert themselves between the sheets causing expansion. Nontronite typically has a chemical composition consisting of more than $\sim 30 \% \mathrm{Fe}_{2} \mathrm{O}_{3}$ and less than $\sim 12 \% \mathrm{Al}_{2} \mathrm{O}_{3}$ ignited basis and formula for nontronite is $\mathrm{Ca}_{5}\left(\mathrm{Si}_{7} \mathrm{Al}_{.8} \mathrm{Fe}_{2}\right)\left(\mathrm{Fe}_{3.5} \mathrm{Al}_{4} \mathrm{Mg}_{1 .}\right) \mathrm{O}_{20}(\mathrm{OH})_{4}$. The dioctahedral sheet of nontronite is composed mainly of trivalent iron $\left(\mathrm{Fe}^{3+}\right)$ cations, although some substitution by trivalent aluminium $\left(\mathrm{Al}^{3+}\right)$ and divalent magnesium $\left(\mathrm{Mg}^{2+}\right)$ does occur (Gates, 2002). Commonly, kaolinite minerals contain silica $45-$ $56 \%$, alumina $9-14 \%$, iron $0-4 \%$, calcium or magnesium absent (Jepson and Browser 1975), yet smectites contain silica $20-37 \%$, alumina $10-25 \%$, iron $5-16 \%$, calcium or magnesium $5-15 \%$, sodium or potassium $5-15 \%$ range (Bain, 1986, Gates, 2002). Clays and clay minerals are very important industrial minerals; they have been in use as raw materials for hundreds of industrial applications due to its availability and low cost. Clays are utilized in agricultural, construction, engineering, environmental remediation, geology, pharmaceuticals, food processing, and many other applications (Murray, 2007). Natural clays are known to rid water underground of heavy metal ions and bacteria. Clay and clay minerals have also been explored as the adsorbents for the removal of heavy metals from aqueous solution. The advantages of using clay minerals as the alternative adsorbents for the removal of heavy metals are high ion sorption/exchange capacity, low permeability, swelling ability, chemical and mechanical stability, and large specific surface area. The adsorption of heavy metals from aqueous solution using clay minerals are influenced by several factors such as $\mathrm{pH}$, temperature, the presence of other compounds, initial concentration (Dos Santos et al. 2015; Kul and Koyuncu, 2010). Many natural clays and their modified forms have been used to remove ammonia from aqueous solutions (Rozic et al. 2000; Bedelean et al. 2010; Zhang et al. 2012; Zhao et al. 2013; Zamparas et al. 2013). Natural clays are abundant, readily available low-cost natural resource which is nontoxic to ecosystem; this makes it a better adsorbent. Over the recent years, research on the modification of clay to increase their adsorbent capacity to remove other contaminants from drinking water other than metals is in progress (Hindawi, 2011).

Clays were reported to play an important role in the environment as natural scavengers of pollutants through ion exchange or/and adsorption. Thus, clays invariably contain exchangeable cations and anions. The prominent cations and anions found on clay surface are $\mathrm{Ca}^{2+}, \mathrm{Mg}^{2+}, \mathrm{H}^{+}, \mathrm{K}^{+}, \mathrm{NH}_{4}{ }^{+}, \mathrm{Na}^{+}, \mathrm{SO}_{4}{ }^{2-}, \mathrm{Cl}^{-}, \mathrm{PO}_{4}{ }^{3-}$ and $\mathrm{NO}_{3}{ }^{-}$. Large surface area, chemical and mechanical stability, layered structure and high cation exchange capacity were shown to be responsible for adsorbent behavior of clays and clay minerals (Cadena et al. 1990). Both Bronsted and 
Lewis type of acidity in clays (Tanabe, 1981) boost the adsorption capacity of clay minerals. The Bronsted acidity arises from protons on the surface formed by dissociation of water molecules of hydrated exchangeable metal cations on the surface. The Bronsted acidity may also arise if there is a net negative charge on the surface due to the substitution of $\mathrm{Si}^{4+}$ by $\mathrm{Al}^{3+}$ in some of the tetrahedral positions and the resultant charge is balanced by $\mathrm{H}_{3} \mathrm{O}^{+}$cations. The Lewis acidity arises from exposed trivalent cations, mostly $\mathrm{Al}^{3+}$ at the edges, or $\mathrm{Al}^{3+}$ arising from rupture of Si-O-Al bonds, or through de-hydroxylation of some Bronsted acid sites. The edges and the faces of clay particles can adsorb anions, cations, and non-ionic and polar contaminants from natural water. The contaminants accumulate on clay surface leading to their immobilization through the processes of ion exchange, coordination or ion-dipole interactions. Sometimes the pollutants can be held through $\mathrm{H}$-bonding, van der Waals interactions, or hydrophobic bonding arising from either strong or weak interactions. The strength of the interactions is determined by various structural and other features of the clay mineral. As far back as 1977, van Olphen had cited the active sites in clays to include: Bronsted acid or proton donor sites, created by interactions of adsorbed or interlayer water molecules; Lewis acid or electron acceptor sites occurring due to dihydroxylation; oxidizing sites, due to the presence of some cations in octahedral positions or due to adsorbed oxygen on surfaces; reducing sites produced due to the presence of some cations, and surface hydroxyl groups, mostly found in the edges, bound to $\mathrm{Si}, \mathrm{Al}$, or other octahedral cations. Clay composites are therefore good adsorbents because of the existence of several types of active sites on the surface. The edge hydroxyl groups have been particularly active for various types of interactions. Clays and modified clays have been reported to adsorb ions of several heavy metals like arsenic, cadmium, chromium, cobalt, copper, iron, lead, manganese, nickel, and zinc from aqueous medium. The adsorption capacities varied from metal to metal and depended on the type of clay used (Bhattacharyya and Sen Gupta, 2008). Composites can be defined as natural or synthesized materials made from two or more materials with significantly different physical and chemical properties which remain separate and distinct at the microscopic or macroscopic scale within the material. Composites are synthesized to combine the desired properties of the materials in the composite.

\section{Materials and Method}

Study area 
The Murchison bay is located to the south of Kampala. It lies in the watershed for Nakivubo channel which drains
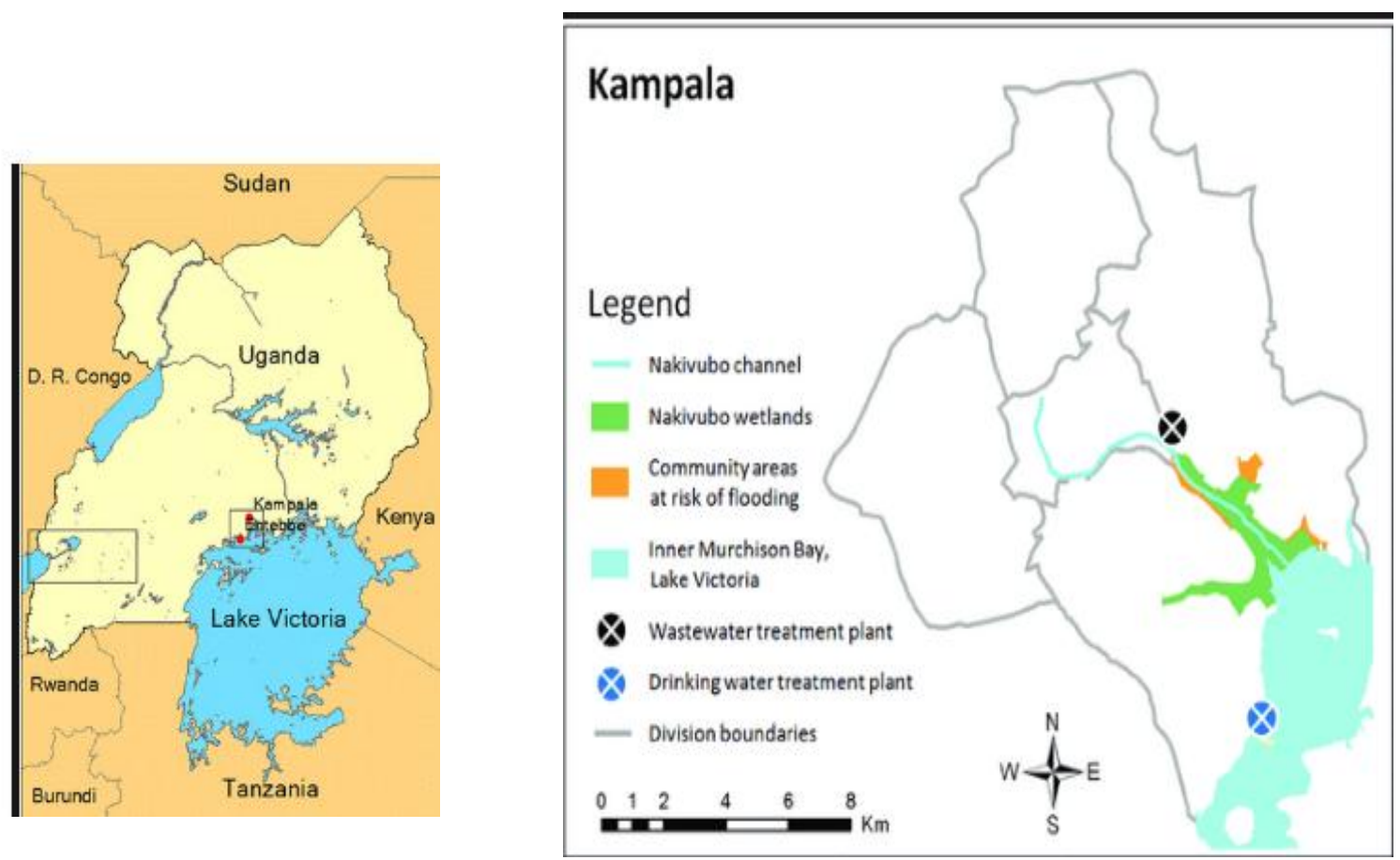

much of the Kampala areas shown in Figure 2.

Figure 2: Map of Uganda showing location of Murchison bay

\section{Sampling of water}

Samples of water (2L) were drawn into plastic bottles, sealed, packed freeze box and transported to the laboratory in Makerere University, where they were stored in a freezer at $4{ }^{\circ} \mathrm{C}$ for future use. The water used in the study was collected at 0,50,100,150 and 200m in the bay south of river Nakivubo. The most important task of water quality analysis is sampling (Abdur et al. 2013).

Water was sampled in brown reagent bottles that had been prewashed with nitric acid, detergent and rinsed with distilled water several times. A total of 10 samples were collected for analysis. The samples were tightly caped and placed in a cool box immediately. They were then transported to the laboratory, and then filtered using whatman filter papers to avoid interference due to turbidity and color. The samples were then kept in a refrigerator at a temperature below $4^{\circ} \mathrm{C}$.

\section{Determination of COD}

To sample $(10 \mathrm{~mL})$ in a reaction flask was added glass beads followed by mercury (II) sulfate solution ( $1 \mathrm{~mL})$, then added potassium dichromate (VI) solution with continuous swirling, then slowly added silver (I) sulfate-sulfuric acid solution $(15 \mathrm{~mL})$. Refluxing apparatus was setup and the mixture was digested over a hotplate for two hours, then cooled. The inside of flask and condenser was rinsed with distilled water $(25 \mathrm{~mL})$ and solution added to flask. Ferroin indicator (2drops) was added to mixture in flask and titrated with $0.025 \mathrm{M}$ ammonium iron (II) sulfate solution to blue end point, Vs. A blank titre on distilled water was also carried out in the same way as was done on sample of water from the bay, $\mathrm{Vb}$. 
$\operatorname{COD}=\underline{8 \times 1000 \times D F x M x V b-V s}$

Volume of sample

Where DF is dilution factor if applied; $M$ is molarity of ammonium iron(II) sulfate solution; $\mathrm{Vb}$ is volume consume by blank and $V s$ is volume consumed by sample. COD is milligrams per liter or ppm.

\section{Preparation of Phosphate Standards}

The standards were prepared according to the standard methods for the examination of water and Waste Water (APHA, 1999). 1000 ppm of standard phosphate solution was prepared by weighing analytical grade potassium dihydrogen orthophosphate $(1.4329 \mathrm{~g})$ and diluting to $1000 \mathrm{ml}$ in a standard volumetric flask using distilled water. In the preparation of $1,2,3,4,5,6$, ppm solution the standard phosphate solution $(0.1 \mathrm{ml}, 0.2 \mathrm{ml}, 0.3 \mathrm{ml}$, $0.4 \mathrm{ml}, 0.5 \mathrm{ml}$ and $0.6 \mathrm{ml}$ ) were respectively diluted to $100 \mathrm{ml}$ with distilled water.

\section{Analysis for phosphate ions}

Each of the standards $(10 \mathrm{~mL})$, blank $10 \mathrm{~mL})$ and samples $(10 \mathrm{~mL})$ were measured into a test tube. $2 \mathrm{ml}$ of combined reagent $(2 \mathrm{~mL})$ were added to the standards, blanks and samples. Phenolphthalein indicator (1 drop) was added to the solutions upon which pink color developed and $5 \mathrm{~N}$ sulfuric acid was added drop wise to discharge the color. Time (10 minutes) was allowed to elapse, after which absorbance of each solution was measured at 880 $\mathrm{nm}$ on a UV-VIS spectrophotometer.

\section{Clay sampling}

The samples were collected at depths in range of $35-150 \mathrm{~cm}$ from the surface to minimize the effect of weathering and contamination.

\section{Preparation of clays}

Raw samples of clays were separately soaked in distilled water, sieved to pass through a mesh of $5.3 \times 10^{-4} \mathrm{~m}$ diameter, dried at $105^{\circ} \mathrm{C}$ and ground to powder using a rolling mill. The clay powders will be stored for future use.

\section{Measuring turbidity of sample}

The sample of water was placed in a tube and shaken vigorously. When gas bubbles disappeared, the sample was transferred to the nephelometer tube. The tube and its contents were inserted in the turbidimeter and turbidity read off.

NTU of sample $=$

$$
A(B+C)
$$

$\bar{C}$

where, $A=N T U$ found in diluted sample; $B=$ volume of dilution water in $\mathrm{mL} ; C=$ sample volume taken for dilution in $\mathrm{mL}$

\section{pH Determination}

The water sample is properly mixed and stirred using a glass rod. Using a watch glass, sample of water $(40 \mathrm{~mL})$ was added to the beaker. The temperature of the water was allowed to stabilize by allowing the sample stand 
for 1 hour while stirring. The temperature of the water was determined and the temperature was adjusted. The $\mathrm{pH}$ of the sample was recorded.

\section{Determination of Iron in water}

The Odyssey spectrophotometer Hach DR 2500 was used.

Part I: Preparation of standard solution

Volumetric flasks were labeled: 0 ppm, 1.0 ppm, 2.0 ppm, 4.0 ppm, 6.0 ppm. Using a pipette $0.0 \mathrm{~mL}, 1.0 \mathrm{~mL}, 2.0$ $\mathrm{mL}, 4.0 \mathrm{~mL}$, and $6.0 \mathrm{~mL}$ of the $100 \mathrm{ppm}$ of $\mathrm{Fe}^{2+}$ solution was added to the appropriate flasks. $0.25 \%$ orthophenanthroline solution $(5 \mathrm{ml})$ was added to each flask. Then distilled water was used to make each solution to $100.0 \mathrm{~mL}$ mark. Each of the solutions made was used to record the absorbance.

Part II: Forming the standard curve

The spectrophotometer was warmed up for 20 minutes. The wavelength was adjusted to $510 \mathrm{~nm}$. The cuvette containing the blank $(0 \mathrm{ppm})$ was inserted in spectrophotometer. Then the cuvette containing the sample was put in the sample compartment with the triangle on the cuvette facing the front of the instrument. The lid was closed. The absorbance of water was recorded and the cuvette removed from the instrument. The cuvette containing sample $(1.0 \mathrm{ppm})$ inserted. The lid was closed. Absorbance of sample was recorded. Absorbance for each of the other standard solutions was recorded following similar steps. The data obtained was used to plot calibration curve.

Part III: Preparation and analysis of the unknown

Test sample of water $(5 \mathrm{~mL})$ was put in volumetric flask. $0.25 \%$ ortho-phenanthroline solution $(5 \mathrm{~mL})$ was added to the same flask and mixture made up $100 \mathrm{~mL}$ mark with distilled water. A cuvette was filled with mixture made. The cuvette was placed in the spectrophotometer and absorbance of solution recorded. Absorbance of other test samples were similarly recorded.

\section{Total solid suspended in water determination}

This was performed following standard method 2540. A known volume of vigorously shaken sample (50mL) was filtered into a pre-weighed glass fibre filter disk fitted to suction pump, and washed successively with distilled water. The filter was carefully removed from the filtration apparatus and dried for an hour at $105^{\circ} \mathrm{C}$ in an oven, cooled in desiccator and re-weighed to constant weight.

\section{Total nitrate in water}

A known volume $(50 \mathrm{~mL})$ of the sample was pipetted into a porcelain dish and evaporated to dryness on a hot water bath. Phenol disulphonic acid $(2 \mathrm{~mL})$ was added to dissolve the residue by constant stirring with a glass rod. Concentrated solution of sodium hydroxide and distilled water was added with stirring to make it alkaline. The solution was filtered in a tube and made up with distilled water $(48 \mathrm{~mL})$. The absorbance was read at $410 \mathrm{~nm}$ using a spectrophotometer after the development of colour.

\section{Results and discussion}

\section{Characterization of Chelel clay sample}


The clays from Chelel were formed by alteration of granitoids, rhyolites, volcanic ash, and dickites in the ultrabasic media. The clay was mined from a valley yet diagenesis took place uphill, the possibility of in situ alteration was unlikely as the clays were eroded. The clays showed was brown or orange due to presence of iron in different oxidation states as well as difference in the mineralogical compositions in the different strata resulting from the levels of alteration and migration of silica.

The mineralogical compositions of clays give hint on the structural, surface and ion-exchange properties of the material. The world over, clays with high smectite content (bentonites and montmorillonites) are used in the manufacture of ion-exchangers and filter aids (Christidis et al. 2001). Chemical analyses of clays have always revealed the class of alumino-silicates to which the analyzed material belongs (Al Zaharan et al. 2000; Gates, 2002). It was useful to establish the elemental constitution of the clay because surface and ion-exchange properties of solids depend on the elements present. The clay contained silica, $44.3 \%$; alumina, $19.4 \%$, iron (III) oxide, $6.2 \%$, calcium oxide, $2.4 \%$, sodium oxide, $3.4 \%$, potassium oxide, $2.6 \%$ and loss on ignition was 9.9 . Basing on elemental composition, Chelel clay ressembled bentonites. On the basis of relative percentages of aluminium, silicon and alkaline metals or alkaline earth metals (Al-Zaharani et al, 2000; Gates, 2002).

The IR absorption spectrum for the natural clay had absorption band at $3640 \mathrm{~cm}^{-1}$ attributed to stretching vibrations of the $\mathrm{OH}$ group while that at $3454 \mathrm{~cm}^{-1}$, the presence of interlayer water. The amount of adsorbed water in clays is related to the deformation vibrations of the $\mathrm{H}-\mathrm{O}-\mathrm{H}$ group $\left(1664 \mathrm{~cm}^{-1}\right)$. The bands at 1042 and $798 \mathrm{~cm}^{-1}$ are attributed to Si-O stretching vibrations (Christidis et al, 1995; Murray, 2008). The bands at 526 and $466 \mathrm{~cm}^{-1}$ correspond to deformation vibrations of $\mathrm{Si}-\mathrm{O}-\mathrm{Al}$ and $\mathrm{Si}-\mathrm{O}-\mathrm{Si}$, respectively (Volzone et al. 1988). The infra-red spectrum for clay sampled from Chelel is shown in Figure 3; with broad peaks at $3700 \mathrm{~cm}^{-1}$ showing presence of water on clay.

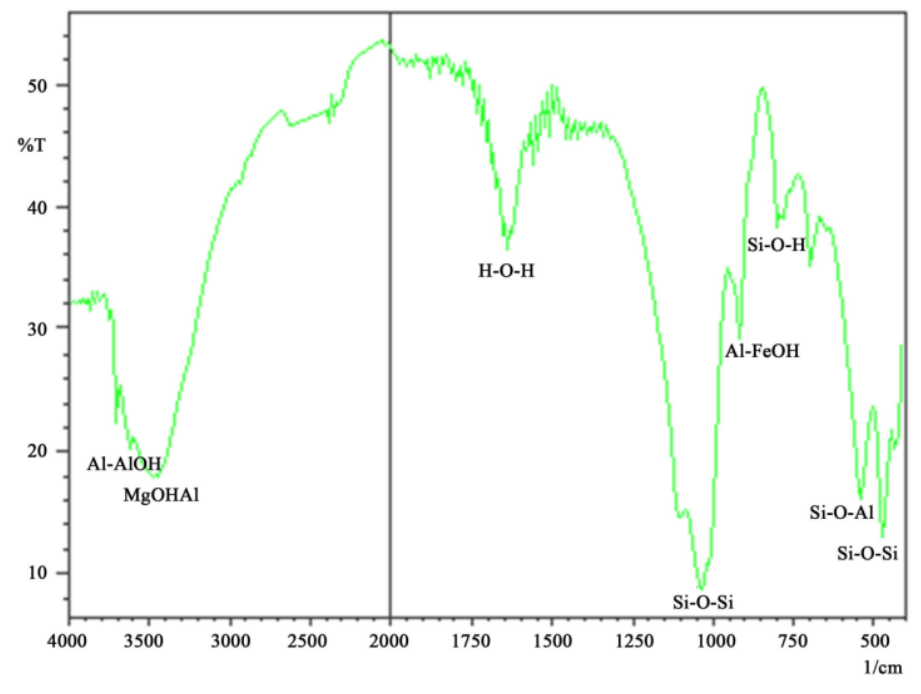

Figure 3: IR spectrum of clay

The IR spectra for Chelel clays showed peaks due to $\mathrm{Mg}-\mathrm{OH}-\mathrm{Al}$ stretch at $3490 \mathrm{~cm}^{-1}$, Al-Al-OH stretch at 3480 $\mathrm{cm}^{-1}, \mathrm{H}-\mathrm{O}-\mathrm{H}$ at $1800 \mathrm{~cm}^{-1}$ and $1620 \mathrm{~cm}^{-1}$, Si-O-Si at $1100 \mathrm{~cm}^{-1}$, Al-Fe-OH at $800 \mathrm{~cm}^{-1}$, Si-O-Al at $600 \mathrm{~cm}^{-1}$ and Si-O-Si at $490 \mathrm{~cm}^{-1}$ showed that these clays conform to the structure of montmorillonite (Murray, 2007).

The XRD pattern for clays sampled from Chelel is shown in Figure 4; with nontronite and kaolinite as main clay minerals. 
Key: smectite (S), illite (I), kaolinite (K), K-fedspars (Kf), plagioclase ( $\mathrm{Pc})$ and quartz $(\mathrm{Q})$

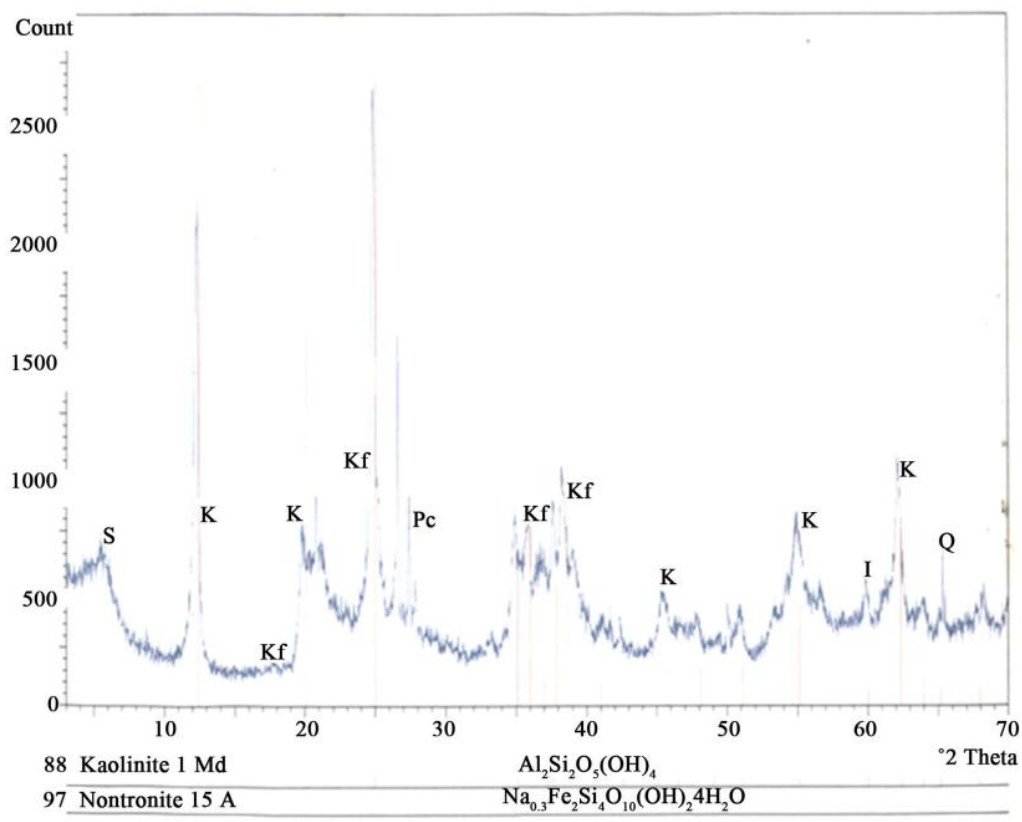

Figure 4: XRD pattern for clay from Chelel

The XRD patterns showed presence of nontronite and kaolinite clays as well as feldspars, quartz and plagioclase as unaltered tuffs. The clay showed presence of smectites, feldspars and plagioclase revealing that they were formed from tertiary-quaternary volcanic ashes or glass. The clay contained quartz, $10.4 \%$, nontronite,50\%, feldspars, $20.0 \%$ and kaolinite, $7.7 \%$ showing that these clays were of the phyllosilicate type. The dominant clay mineral in the clay sample was nontronite. The smectite/kaolinite ratios for Chelel deposits varied between 1:4 and 1:0.13 showing that weathering took place in alkaline medium and kaolinitization of the clay was a separate process (Christidis et al. 1993). Basing on elemental and mineralogical compositions as well as X-ray and infrared spectra patterns, the clay satisfied the formulae $(1 / 2 \mathrm{Ca}, \mathrm{Na})_{0.33}\left(\mathrm{Mg}, \mathrm{Fe}^{+2}\right)_{3}(\mathrm{Si}, \mathrm{Al})_{4} \mathrm{O}_{10}(\mathrm{OH})_{2} \cdot 4 \mathrm{H}_{2} \mathrm{O}$ and $\mathrm{Ca}_{5}\left(\mathrm{Si}_{7} \mathrm{Al}_{.} \mathrm{Fe}_{.2}\right)\left(\mathrm{Fe}_{3.5} \mathrm{Al}_{.4} \mathrm{Mg}_{1 .}\right) \mathrm{O}_{20}(\mathrm{OH})_{4}$ and was named nontronite or Fe-montmorillonite (Gates, 2002; Murray, 2008; Mukasa-Tebandeke et al. 2015).

\section{Characterization of Murchison bay waters}

The parameters used to assert whether a water resource is safe or polluted include chemical oxygen demand (COD), biological oxygen demand (BOD), $\mathrm{pH}$, turbidity, concentration of iron(II), total suspended solids (TSS), nutrient concentration and others. Of these parameters, Murchison bay waters sampled on 14 $4^{\text {th }}$ December, 2018 showed COD ranging from to 78 to $52 \mathrm{mgl}^{-1}$, turbidity ranging from 68 to $42 \mathrm{NTU}$, $\mathrm{pH}$ ranging from 7.6 to 6.8 ; iron (II) concentration ranging from 3.8 to $3.4 \mathrm{mgl}^{-1}$; TSS ranged from 3.8 to $3.4 \mathrm{mgL}^{-1}$; TP ranged from 0.25 to $0.22 \mathrm{mgL}^{-1}$ yet TN ranged from 59 to $25 \mathrm{mgL}^{-1}$ in a distance ranging from $0 \mathrm{~m}$ to $200 \mathrm{~m}$ into the bay. This revealed the impurities were dispersing as we moved towards the lake. The permissible published parameters of safe fresh water sources are as follows; COD $10.0 \mathrm{mgl}^{-1}$, turbidity $5 \mathrm{NTU}, \mathrm{pH}$ range of 5-9 and iron (II) concentration of $2.0 \mathrm{mgl}^{-}$ ${ }^{1}$ (EPA). Basing parameters published, the waters of Murchison bay can be declared polluted.

\section{Variations in turbidity of water}


The turbidity of water decreased as we moved along the bay towards the lake due dilution as influent from Nakivubo channel got mixed with waters from the lake. So suspended solids became dispersed leading to more and more clarity of the water as one approached the lake. This could have resulted from simple dilution or and neutralization of charges on the impurities in the water leading to massive settling of solids from the water to bottom of the bay. The turbidity of water before and after treatment with clay powder was recorded. The turbidity of water significantly decreased as a result of interactions between MB waters and Fe-montmorillonite from Chelel because the clay interacted with the suspended solids in the water by either adsorption of the solids on the clay surface or neutralization of charges on the suspended particles by the clay. Natural nanocomposites can easily adsorb organic and inorganic solids on the surface sites (Syafalni et al. 2013). Adsorptive and electrostatic charges interactions removed suspended solids and resulted in decreased turbidity of water being purified. The data obtained on changes in turbidity of MB water on interaction with clay was plotted in Figure 5; and it revealed that highest decrease in turbidity was observed when concentration of clay was $0.4 \mathrm{gl}^{-1}$ and thereafter addition of higher concentrations of clay powder caused less significant changes in turbidity. Thus proving what earlier workers had published (Syafalni et al. 2013; Jiang et al, 2004). So clay worked to the optimum at $0.4 \mathrm{~g} / \mathrm{L}$ concentration.

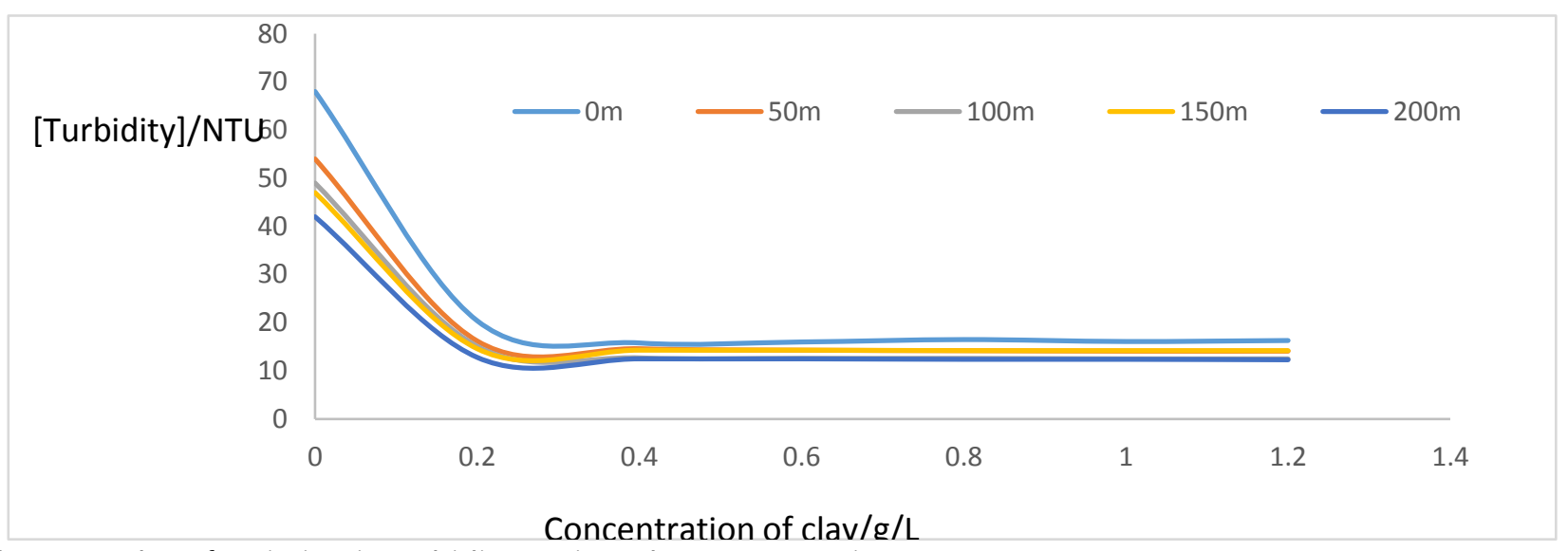

Figure 5: Plot of variation in turbidity against clay concentration

The turbidity decreased as concentration of clay increased from 0.1 to $0.4 \mathrm{gl}^{-1}$ because there was increasing effective coagulation and flocculation of suspended impurities from water caused by clay powder used. So as concentration of clay was increased from 0 to $0.4 \mathrm{gl}^{-1}$, the clarity of water increased because increased concentration of clay lead to increased electrostatic forces of interaction between the clay powder and the impurities suspended in water. So more and more flocs of inorganic and organic matter formed and this led to decrease in turbidity of the water once the flocs were filtered off. The decrease in turbidity was reported to have resulted from removal of iron (II) ions from solution by the clay (Tahir and Rauf, 2004) but this should be extended to include almost all impurities in MB water. The results in Figure 5 agree with the fact that optimum adsorption of inorganic and organic pollutants on clay is achieved when the concentration of clay is $0.4 \mathrm{gl}^{-1}$ (Syafalni et al. 2013) because further increase in concentration of clay resulted in insignificant changes in turbidity of clarified water. So optimum neutralization of charged particle in polluted water of MB and optimum adsorption of impurities on the same clay sample would be attained at this concentration. Water treatment therefore requires only $0.4 \mathrm{~g}$ of clay per liter of water clarified.

\section{Variation of COD}

As Chemical Oxygen Demand (COD) is a measure of the total quantity of all inorganic and organic oxidizable impurities in the water and wastewater yet Biochemical Oxygen Demand (BOD) is a measure of, the amount of oxygen that require for the bacteria to degrade the organic components present in water and wastewater; we undertook to determine COD so as to obtain a representative value of inorganic and organic pollution levels of waters of MB. There was decrease in COD with increase in distance into the MB showing level of pollution water 
decreased as we approached Lake Victoria. This happened as a result of dilution because waters of the lake diffuse in $\mathrm{MB}$ as well as electrostatic neutralization of charges on particle MB water when it mixed with waters of the Lake leading massive settling of pollutants at base of the bay. The data obtained on COD have plotted in Figure 6. The results in Figure 6 revealed there a sharp fall in COD as concentration of clay increased from 0.0 to $0.4 \mathrm{gl}-1$ due more pronounced adsorptive tendencies for the inorganic and organic pollutants on clay minerals as well as neutralization of electrostatic charges on suspended particles in MB waters by the clay composites leading to flocculation. So filtration of the water after interacting with clays almost exhaustive eliminated all oxidizable matter in clarified water from MB. The COD of samples was computed and recorded.

The COD needed to oxidize organic and inorganic impurities in the waters from MB decreased as the bay was traversed from $0 \mathrm{~m}$ to $200 \mathrm{~m}$ because concentration microorganisms in water decreased. This indicate dilution of water pollutants as the water headed towards the lake (Akurut et al. 2017).

The highest average decrease in COD was attained using clay concentration of $0.4 \mathrm{gl}^{-1}$ representing $75.5 \%$ fall in in this experiment. This indicated that the clay served very well as flocculent and coagulant for the impurities and microorganisms in the bay waters. However, the percentage fall in COD is less than that was obtained as $90.6 \%$, when Syafalni et al. 2013 treated sewage with bentonite. The value obtained in this study is comparable to what was obtained in literature because the study used Fe-montmorillonite which cannot be as effective as $\mathrm{Na}$ montmorillonite. The Na-montmorillonite has much higher surface area and ion-exchange capacity than Femontmorillonite used in this study. However, the clay form Chelel is good enough to overcome remove inorganic, organic, and microbial pollutants from water. When low COD is obtained, the target for wastewater management would have been achieved because removal of COD is indicative of elimination of inorganic and biodegradable materials from water (Jiang et al. 2004).

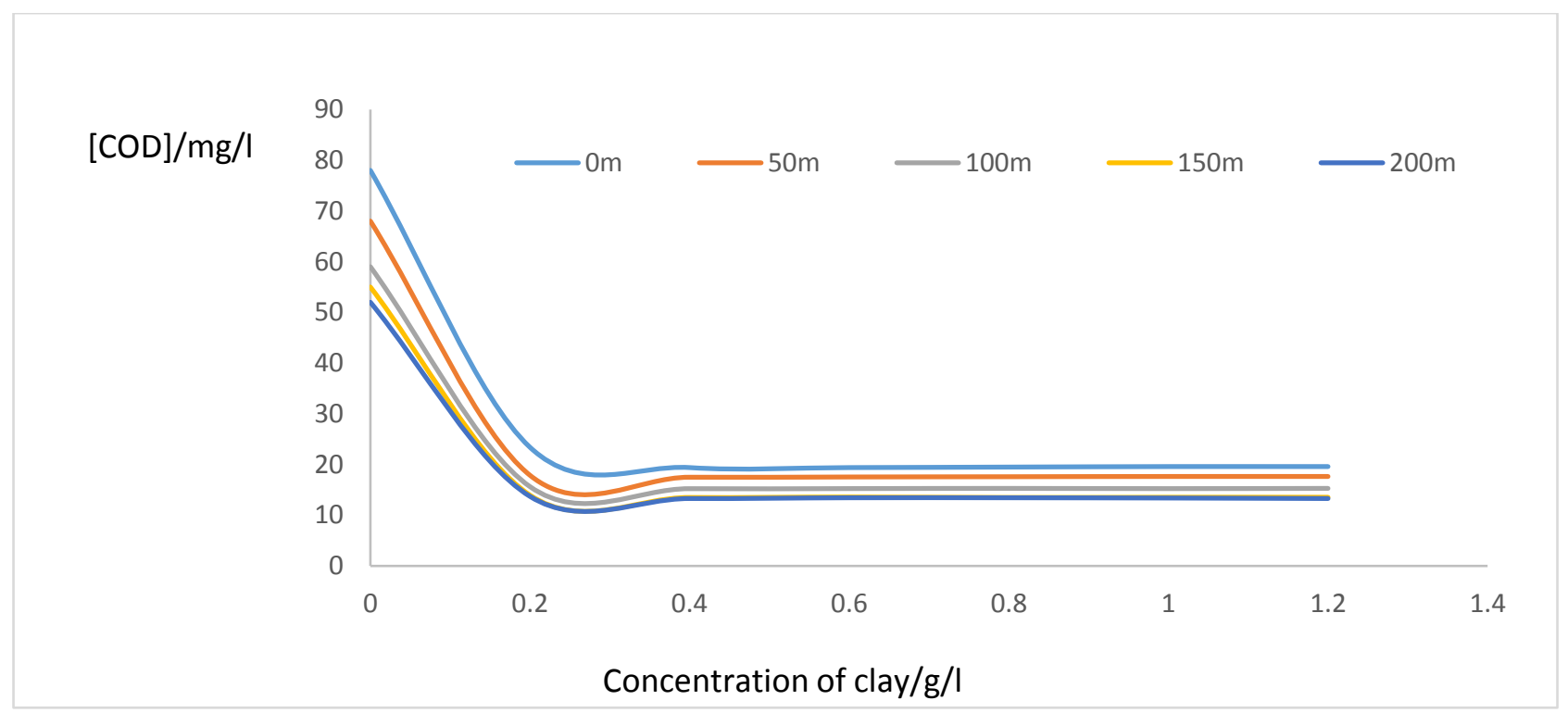

Figure 6: Plot of variations of COD against clay concentration

The figure 6 shows that the optimum coagulation and flocculation of impurities in MB water occurred at clay concentration of $0.4 \mathrm{gl}^{-1}$ because COD reached the minimum value at this concentration (Syafalni et al, 2013). So effective adsorption using lower concentration of clay completely removed the ions in the MB water through electrostatic and mechanistic bridging effects of the clay used (Bacchin et al. 2011; Chatterjee et al, 2002). Treatment of MB water with higher concentration of clay than $0.4 \mathrm{~g} / \mathrm{L}$ resulted in increased clarity of water because the added clay availed more adsorption sites for impurities in the water Al-Bastaki and Banat, 2004). There was no observed influence on removal of COD to the location or point of sampling of water in the MB. Similarly, then 
initial concentration of COD caused less significant influence on the rate of fall of COD probably because the coagulation and flocculation processes were highly favored during the clarification of MB water and the clay provided large enough number of sites to adsorb and neutralize charges on impurities in the water tested.

When MB water was treated with $0.4 \mathrm{gl}^{-1}$ of clay, both inorganic and organic pollutants were removed from water (Zhu et al. 2008) resulting in highest fall in COD of $78.1 \%$. The fact that the clay achieved $78 \%$ decrease in COD paves way to replacing alums that are thought to cause the Alzheimer's disease even though they are reported to attain 80-90\% efficiency at removing COD (Chatterjee et al, 2009). The percentage decrease in COD was plotted in Figure 6a. The available data showed that fall in COD increased with increase in concentration of clay used up to $0.4 \mathrm{~g} / \mathrm{L}$. Beyond $0.4 \mathrm{~g} / \mathrm{l}$, the decrease in COD remained fairly constant.

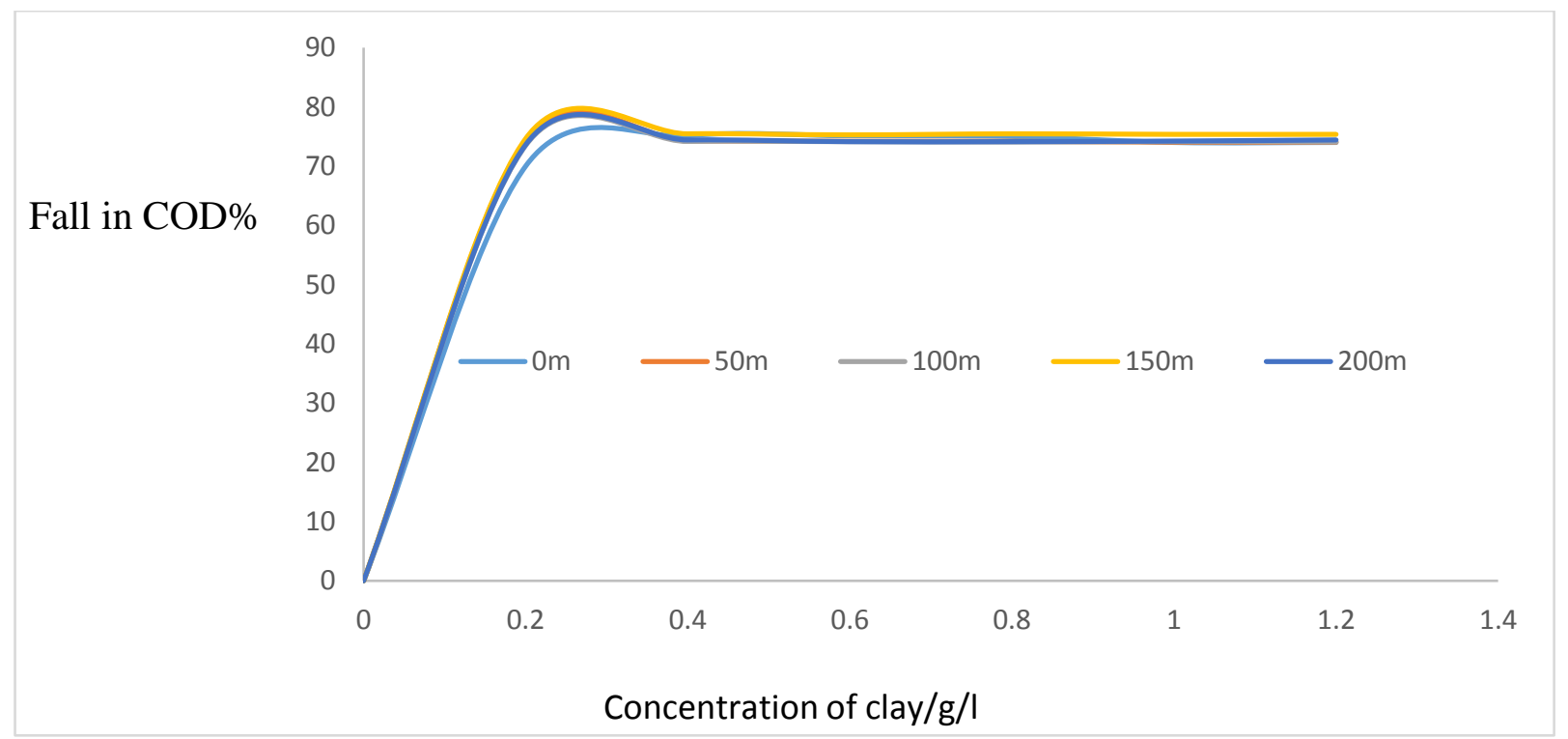

Figure 6a: Plot of percentage fall in COD versus concentration of clay

The percentage decrease in COD indicated that the clay used worked well, efficiency greater than $73 \%$.

\section{Variation of $\mathrm{pH}$}

The $\mathrm{pH}$ of water sampled from Murchison bay was higher than 7, the neutral $\mathrm{pH}$ indicating that the water contained basic contaminants which needed to be removed to restore neutrality. Although the $\mathrm{pH}$ of the water was within the acceptable range for the environmental protection agency(EPA) an attempt to determine how it varies after treating the water with the clay was necessary. During the study the $\mathrm{pH}$ fell from as high as 7.6 to as low as 6.1. The data on changes in $\mathrm{pH}$ and concentration of clay used was plotted in Figure 7. The results in Figure 7 revealed that clay removed pollutants in the MB water with consequence that $\mathrm{pH}$ decreased. 


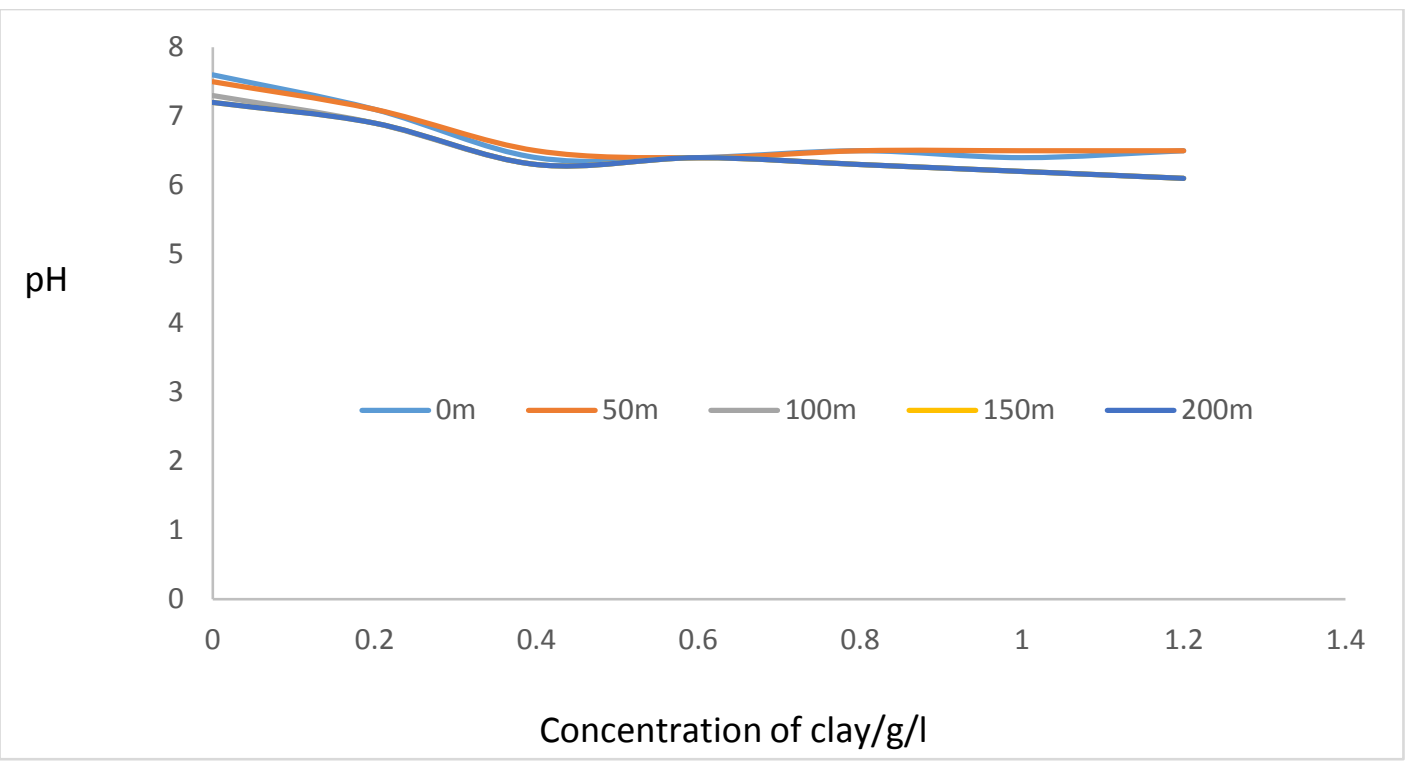

Figure 7: Plot of variations in $\mathrm{pH}$ of $\mathrm{MB}$ water versus concentration of clay

The changes in $\mathrm{pH}$ were only slight, but the greatest decrease in $\mathrm{pH}$ occurred when the lowest concentration of clay used was $0.4 \mathrm{gl}^{-1}$ implying the adsorption of pollutants and neutralization of electrostatic charges on particles in $\mathrm{MB}$ water attained. This result coincided with what was published by researchers on treatment of sewage and wastewater (Syalfalni et al. 2013, Tahir and Rauf, 2004). Determination of pH of treated water is important in relaying information on removal of inorganic and organic pollutants from water (Inglezakis et al. 2007).

\section{Variation of iron (II)}

The concentration of iron in drinking water should not exceed $0.30 \mathrm{mg} /$ liter. Since the daily nutritional requirement of iron is 1 to $2 \mathrm{mg}$, the standard is for aesthetic reasons rather than toxicity. It should be pointed out, however, that iron concentrations of above $1.0 \mathrm{mg} /$ liter are detrimental to many freshwater fish (EPA). The level of heavy metal pollution of a water resource can be trace through determining concentration of iron. In this study the concentration of iron(II) ions varied from as high as 3.8 to as low as $3.4 \mathrm{mgl}^{-1}$ in the raw waters sampled from MB. These high values implied that the MB water is polluted because the allowed limit is $2.0 \mathrm{mgl}^{-1}$ (EPA). The concentration of iron in water treated with clays fell to as low $2.0 \pm \mathrm{mgl}^{-1}$ a sign showing that there was effective uptake of iron (II) ions from water by the clay used, hence rendering water safer that it was collected. The data obtained on variation of concentration of iron(II) ions with concentration of clay was plotted in Figure 8. The results in Figure 8 indicate that the clay mineral used bound and removed iron from MB water. 


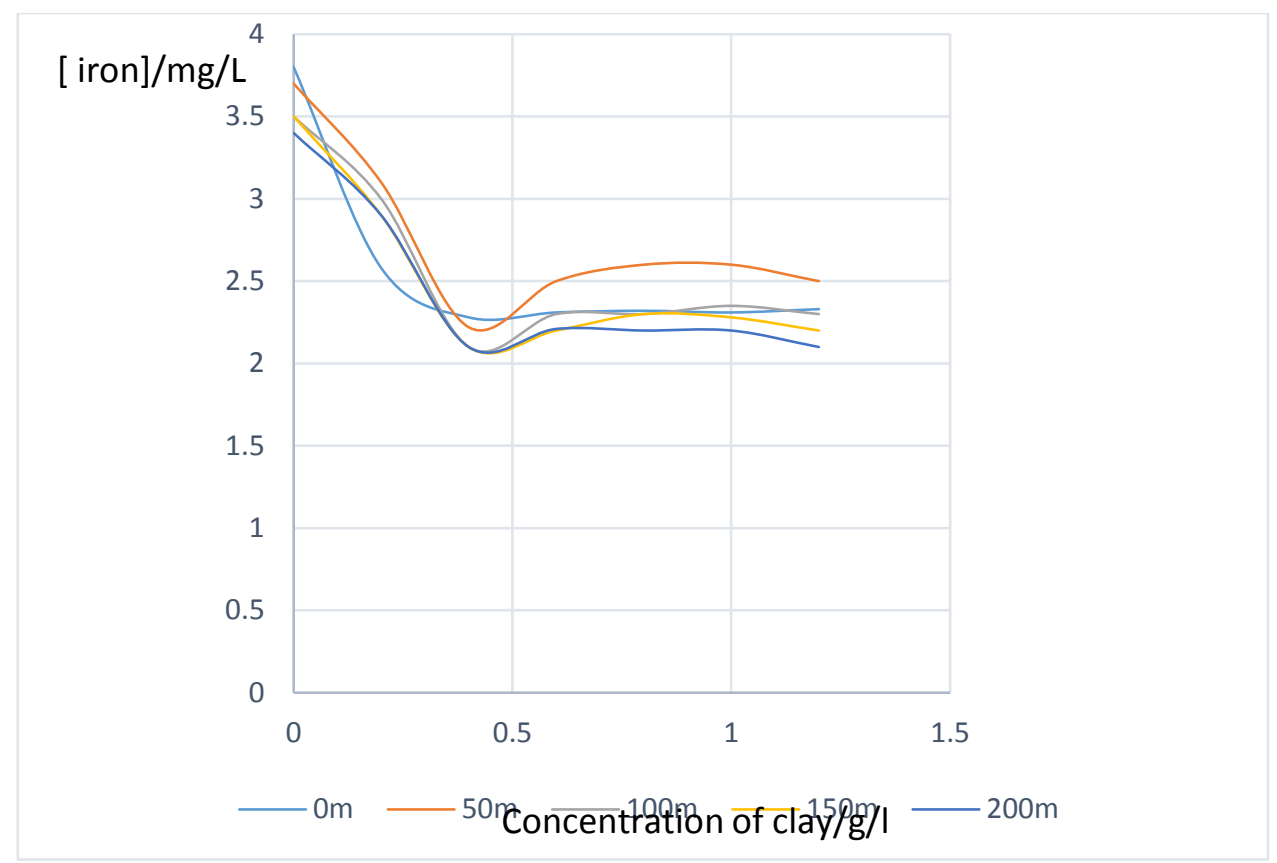

Figure 8: Plot of variation in concentration of iron (II) ions versus concentration of clay used

There was a sharp decrease in concentration of iron(II) ions when the concentration of clay increased from 0.0 to $0.4 \mathrm{gl}^{-1}$ probably because within this concentration range the clay would effectively adsorb the iron(II) ions on its surface. So rendering the MB waters safer for animal health. Increase in concentration of clay used beyond $0.4 \mathrm{gl}^{-}$ ${ }^{1}$ yielded less significant changes in concentration of iron(II) ions in the water probably because effective ionexchange between the clay and iron(II) in water had already occurred or the electrostatic charges on clay and those on pollutants in MB water had reached the highest possible. So further increase in concentration of clay would not yield proportionate decrease in concentration of iron (II) ions in water being clarified. The removal of iron (II) ions from solution by the clay was reported to have resulted in decreased turbidity (Tahir and Rauf, 2004). Although the recommended that the concentration of iron in drinking water should not exceed $0.30 \mathrm{mg} / \mathrm{liter}$ (EPA) our results did not attain such a low value but still showed that pollution due to iron (II) ions and heavy metals could minimized by treating MB waters with clay. There was no observed influence on removal of iron to the location or point of sampling of water in the MB. Similarly, the initial concentration of iron did not cause significant influence on the rate of fall of concentration of iron probably because the adsorption and ion-exchange processes were highly favored during the clarification of MB water and the clay provided large enough number of sites to adsorb or/and exchange heavy metal ions in the water tested. 


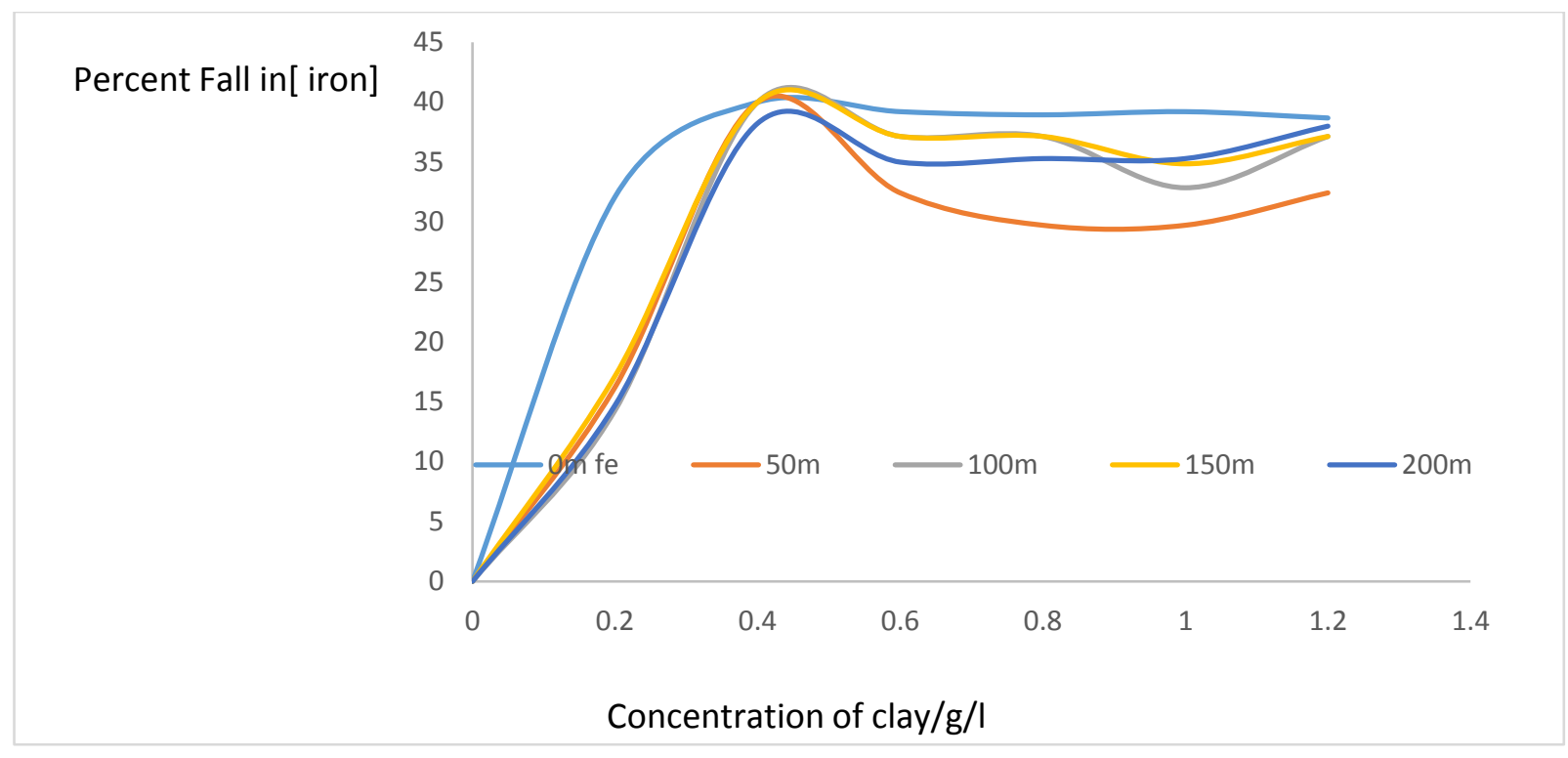

Figure 8a: The efficiency of clay at removing iron from MB water

The mean efficiency with which the $0.4 \mathrm{~g} / \mathrm{L}$ concentration clay removed iron from MB water was $39.65 \pm 0.20 \%$. This showed that the alumino-silicate mineral had a low efficiency at picking iron (II) from MB water probably due to the low $\mathrm{pH}$ of water being studied as well as the clay itself containing iron.

\section{Variations in total phosphate ion, TP concentration}

The TP values obtained on the samples ranged from 0.22 to $0.25 \pm 0.05 \mathrm{mgl}^{-1}$ showing that the concentration was nearly uniform in the water save for experimental errors that could have caused statistical variations. The determined phosphate ion concentration in MB is higher than what was published, $0.022 \mathrm{mgl}^{-1}$ for Nyanza gulf (Heckey and Bugennyi, 1992); $0.1-4.5 \mathrm{mgl}^{-1}$ (Akurut et al. 2017, 2014) revealing that the extent of pollution is rising steadily as time passes. The determined concentration of $P$ in $M B$ water is above the maximum recommended to be present in freshwater for drinking water. (EPA). The values are large enough to warrant algal blooms in MB water but are much less than what was obtained earlier years (Akurut et al. 2017). These values showed water in $\mathrm{MB}$ is heavily polluted either by sewage or fertilizers used in the farms in the valleys from which this water collects to join Nakivubo channel. However, MB waters are less polluted than springs in western rift valley of Kenya (Swammy et al. 2018). The data obtained on variation of concentration of phosphate ions in $\mathrm{MB}$ with concentration of clay used was plotted in Figure 9. The results in Figure 9 have revealed that effective binding of phosphate ions on clay as well neutralization of electrostatic charges on particles took place with the clay concentration range of 0.0 to $0.4 \mathrm{gl}^{-1}$ because it is within this range of concentrations that the concentration of phosphate ions fell greatly. Analysis of phosphates could be improved by applying the high point standard method which prevent the interference due to silicates based on the rates of reactions between the phosphate and silicates. The kinetics of formation of a complex between molybdenum ions in the presence of silicates and phosphates could be applied for water analysis. Since this was not done, the phosphate concentration could have been exaggerated due to silicate ion interference. 


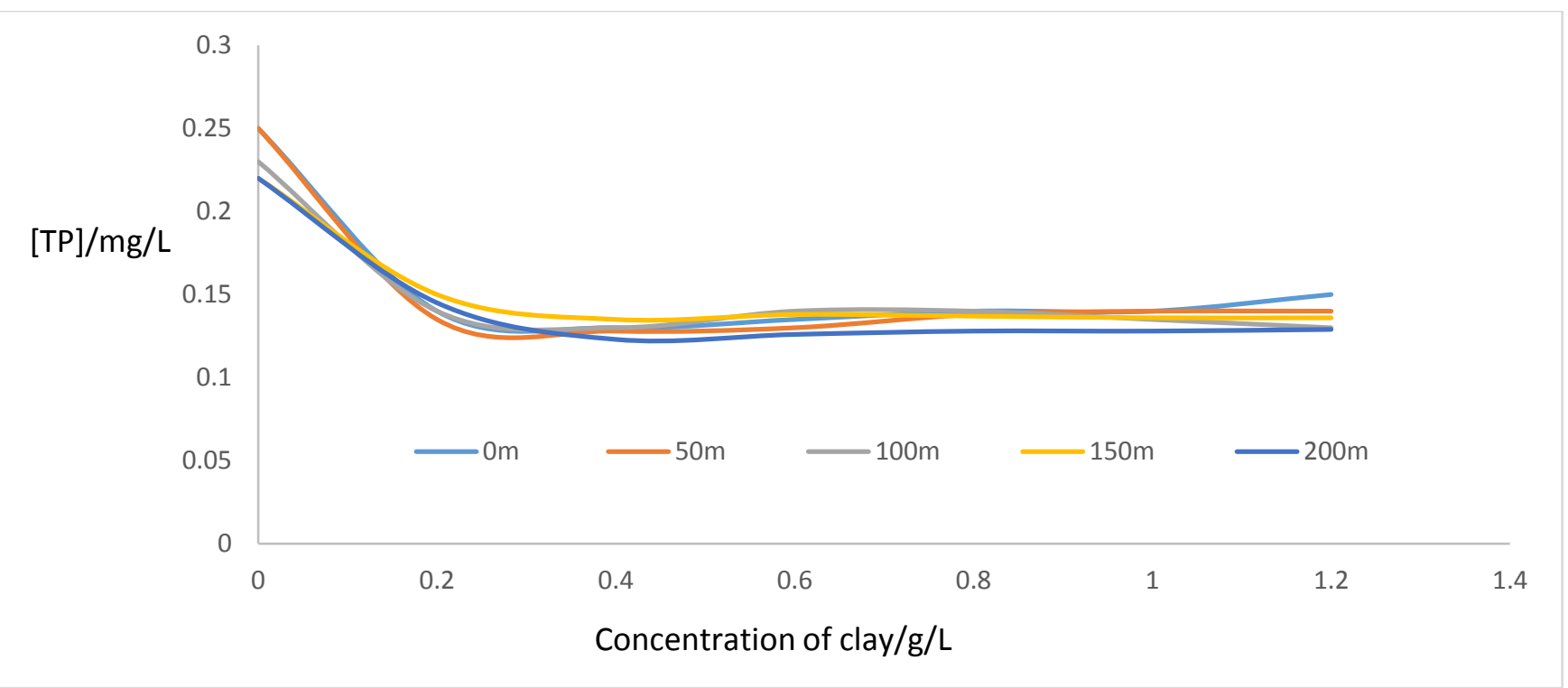

Figure 9: Plot of variations in total phosphate versus clay concentration

The data in Figure 9 depicts that effective adsorption of phosphate ions on clay or and neutralization of charge by clay occurred as concentration of clay increased from 0.0 to $0.4 \mathrm{gl}^{-1}$. This result is supported by what was published when it was found that $0.4 \mathrm{gl}^{-1}$ bentonite would effectively coagulate and flocculate sewage (Syafalni et al. 2013). So clay under study effectively acted on phosphate pollution the same way. However, manmade sources of phosphate like human sewage, agricultural run-off from crops, sewage from animal feedlots, vegetable and fruit processing, chemical and fertilizer use or manufacturing, and detergents could have introduced the phosphate in MB waters (John, 1993). High phosphate concentrations in water increased rates of plant growth and proliferation of planktonic and epiphytic and epibenthic algae making MB water green in color (Mainstone and Parr, 2002). Phosphate concentration was generally high in MB samples. There is need to use sustainable farming methods to avoid influx of nutrients into the water bodies and impact on the quality of fresh water systems. As clays possess Bronsted acidity, the edges and the faces of clay particles adsorbed anions, cations, and non-ionic and polar contaminants from MB water. The contaminants accumulated on clay surface became immobilized through either ion exchange, coordination or/and ion-dipole interactions processes. The pollutants could be held through hydrogen bonding, van der Waals interactions, or hydrophobic bonding arising from either strong or weak interactions. The strength of the interactions is determined by various structural and other features of the clay mineral. As far back as 1977, van Olphen had cited the active sites in clays to include proton donor sites, created by interactions of adsorbed or interlayer water molecules; electron acceptor sites occurring due to dihydroxylation; oxidizing sites, due to the presence of some cations in octahedral positions or due to adsorbed oxygen on surfaces; reducing sites produced due to the presence of some cations, and surface hydroxyl groups, mostly found in the edges, bound to $\mathrm{Si}, \mathrm{Al}$, or other octahedral cations. Clays are therefore good adsorbents because of the existence of several types of active sites on the surface. The percentage decrease in phosphate concentration shown in Figure $9 a$ varied from as low as 37 to $48.8 \pm 0.5 \%$. The highest percentage fall in phosphate concentration was observed at clay concentration of $0.4 \mathrm{gl}^{-1}$ indicating that the clay worked optimally. 


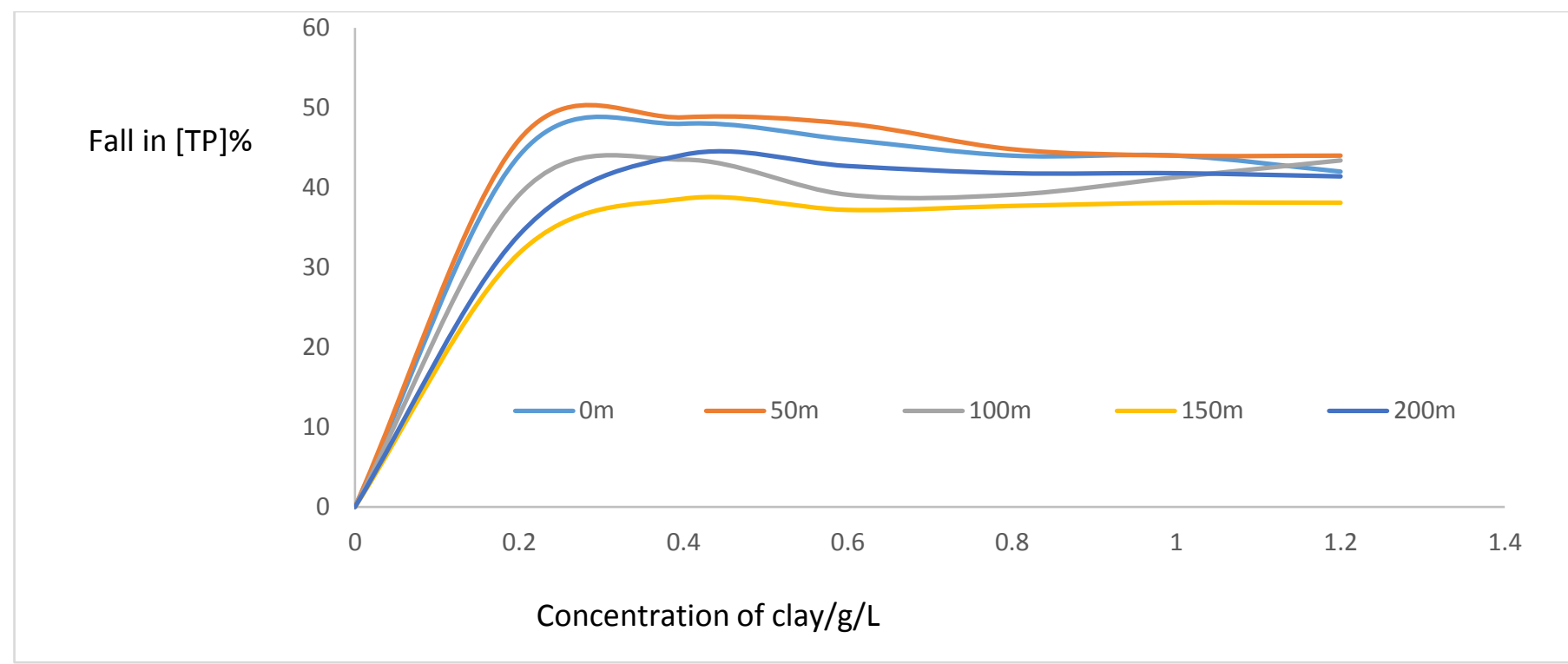

Figure 9a: Plot of percentage fall in phosphate concentration versus clay concentration

The mean efficiency with which clay at $0.4 \mathrm{~g} / \mathrm{L}$ concentration removed phosphate ions was found to be $44.6 \pm 1.63$ $\%$ which is less than the efficiency at which COD was removed probably because the clay contained iron. There was competition between complexation reaction between iron and phosphate, adsorption and discharge of charges on ions as the ions approached the clay lattice. There was no observed influence on removal of phosphate to the location or point of sampling of water in the MB. Similarly, then initial concentration of phosphate ions caused less significant influence on the rate of fall of concentration of phosphate ions probably because the adsorption and ion-exchange processes were highly favored during the clarification of MB water and the clay provided large enough number of sites to adsorb, exchange or/and neutralize charges on phosphate or anions in the water tested.

\section{Variations in nitrate concentration}

The nitrate/nitrogen concentration of water sampled in December 2018 ranged from 12.3 to $18.2 \pm 0.3 \mathrm{mgl}^{-1}$ indicating nitrate pollution in $\mathrm{MB}$ has risen in the recent past as compared to what was published earlier showing range from as low as 6 to $17 \mathrm{mgl}^{-1}$ (Akurut, et al. 2017, 2014a, 2014b) 0.005 to $0.037 \mathrm{mgl}^{-1}$ (Mavuti and Litterick, 1991). The rise in nitrate pollution is due sewage spillage, fertilizer application in farms near or wetlands that drain water runoff in the Nakivubo channel. The data obtained on variation nitrate concentration in MB water with concentration was used to plot Figure 10. The results in Figure 10 revealed the was progressive decrease in concentration of nitrate ions in MB waters as concentration of clay increased revealing that the clay effectively adsorbed and or neutralized the charges on the nitrate ions in solution hence improving the quality of water that was clarified. 


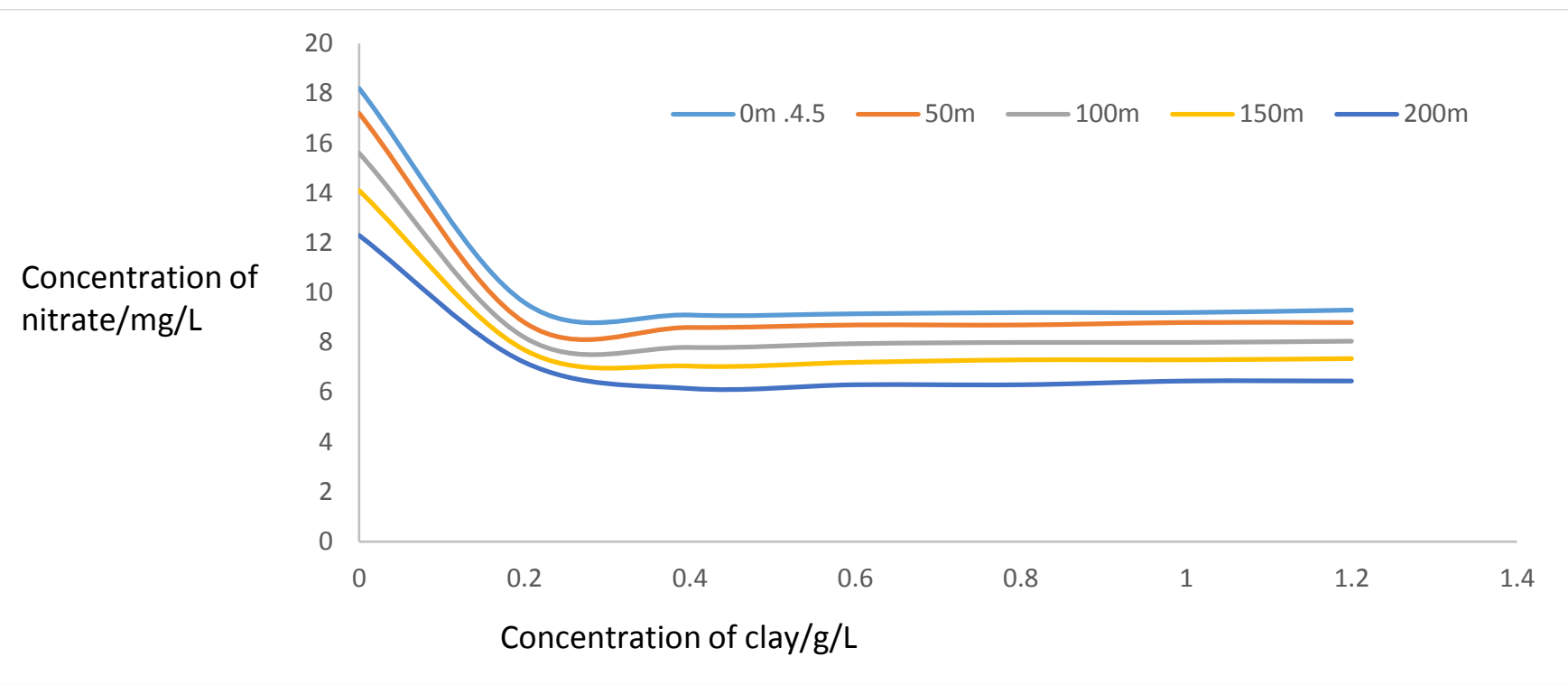

Figure 10: Plot of variation of concentration of nitrate ions in MB with concentration of clay

Several researches have reported the on the ongoing increase in pollutant loading in the MB waters (Akurut et al, 2018; 2014; Banadda et al. 2009; Luyiga et al. 2015) without detailing how the pollution can be reduced. In this study we have found that natural Fe-montmorillonite clay from Chelel amended pollution of water in MB to at least $76 \%$ efficiency of removing impurities in MB water. The nitrate ions accumulated on clay surface were immobilized through the processes of ion exchange, coordination or ion-dipole interactions. The strength of the interactions is determined by various structural and other features of the clay mineral. As far back as 1977, van Olphen had cited clays to possess reducing sites produced due to the presence of some cations, and surface hydroxyl groups, mostly found in the edges, bound to $\mathrm{Si}$, Al, or other octahedral cations. It is probable that these sites played a vital role in removing anionic contaminants from MB water. The Chelel clay was therefore a good adsorbent for nitrate ions because of the existence of several types of active sites on its surface. There was no observed influence on removal of nitrate ions to the location or point of sampling of water in the MB. Similarly, then initial concentration of nitrate ions did not cause significant influence on the rate of fall of concentration of nitrate ions probably because the adsorption and/or ion-exchange of nitrate ions to or with clay were highly favored during the clarification of MB water and the clay provided large enough number of sites to adsorb and exchange ions in the water tested.

\section{Variations in total suspended solids, TSS}

The total amount solids suspended in waters of MB decreased with distance towards the lake from 59 to $25+.1 .32$ $\mathrm{mgl}^{-1}$ but was earlier observed to vary from 42 to $56 \pm 1.32$. $\mathrm{mgl}^{-1}$ (Akurut et al. 2018). The variations in TSS must have resulted from dilution of water in MB by that from the lake and neutralization of electrostatic charges on particles in water resulting from mixing of the waters of the lake and MB leading to massive settling of suspended solids. However, presence of such a large mass of suspended solids in water is indicative of contamination by soluble and insoluble materials in water carried from the streams that feed the MB. This showed that as KCCA paved more areas of the Kampala city, more drainage canals were constructed and the volume of wastewater that runs very fast to $M B$ is larger than ever. Hence more suspended solids reach $M B$ than ever before leading due to flooding. So higher rate of pollution in the MB could be due to the ongoing wetland encroachment and rapid increase in the pollutant loading in the streams flowing to the MB. Consequently, the TSS is large. The data obtained on variations of TSS with concentration of clay used to clarify the water was plotted in Figure 11. The results in Figure 11 showed sharp decrease in TSS as concentration of clay increased from 0.0 to $0.4 \mathrm{gl}^{-1}$ indicating effective flocculation in addition to adsorption had occurred. There was insignificant change in TSS 
when the concentration of clay used was increased beyond $0.4 \mathrm{gl}^{-1}$ probably because the electrostatic charges on suspended and dissolved solids had been neutralized and there was no further reaction with added clay beyond the optimum concentration of $0.4 \mathrm{gl}^{-1}$ (Syafalni et al. 2013)

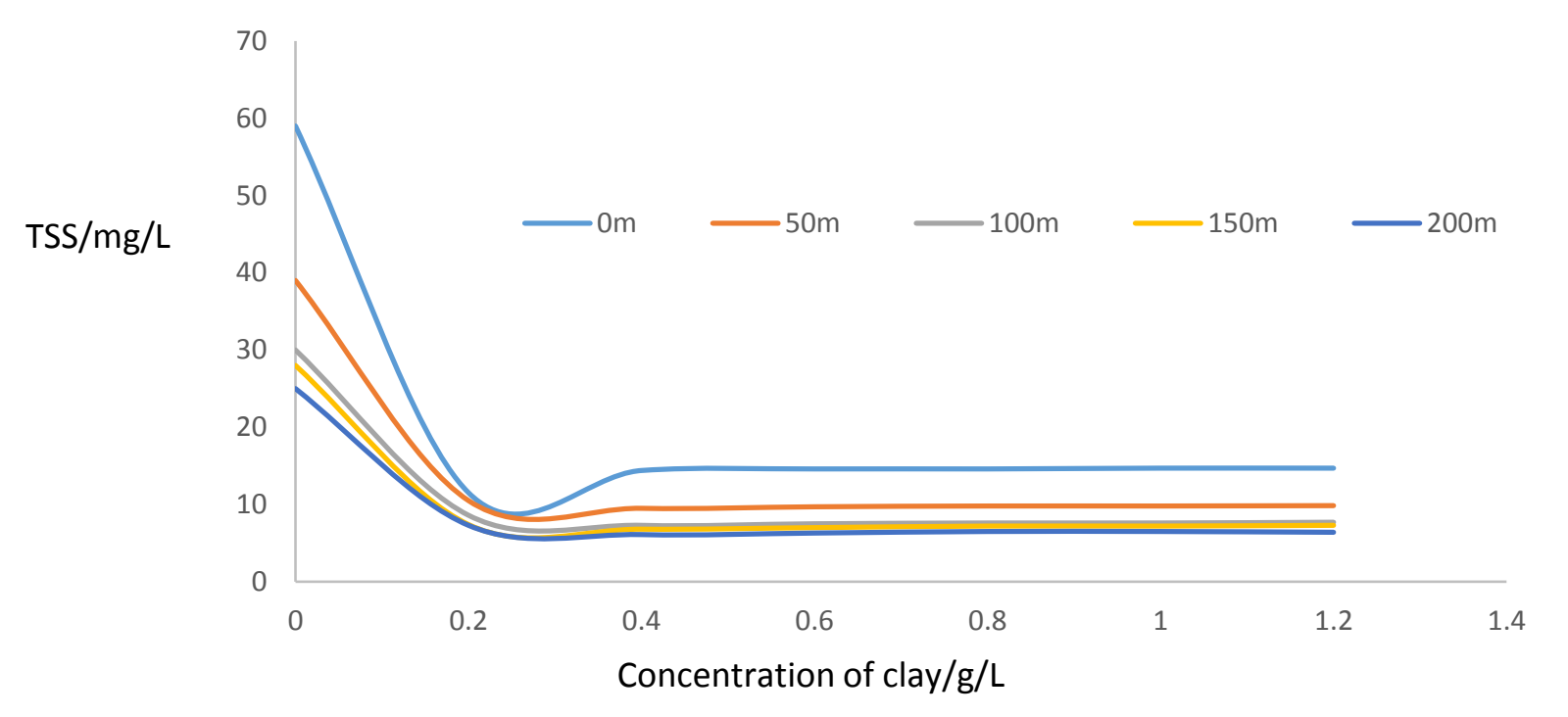

Figure 11: Effect of clay concentration on TSS

The mean decrease in TSS on Figure 11a attained high value of $76.7 \pm 0.45 \%$ fall when the clay concentration was $0.4 \mathrm{gl}^{-1}$ indicating optimum reactions had been achieved. This has been interpreted as showing that the clay worked well on removing suspended solids from MB waters. So water from MB can be clarified using natural clay composites.

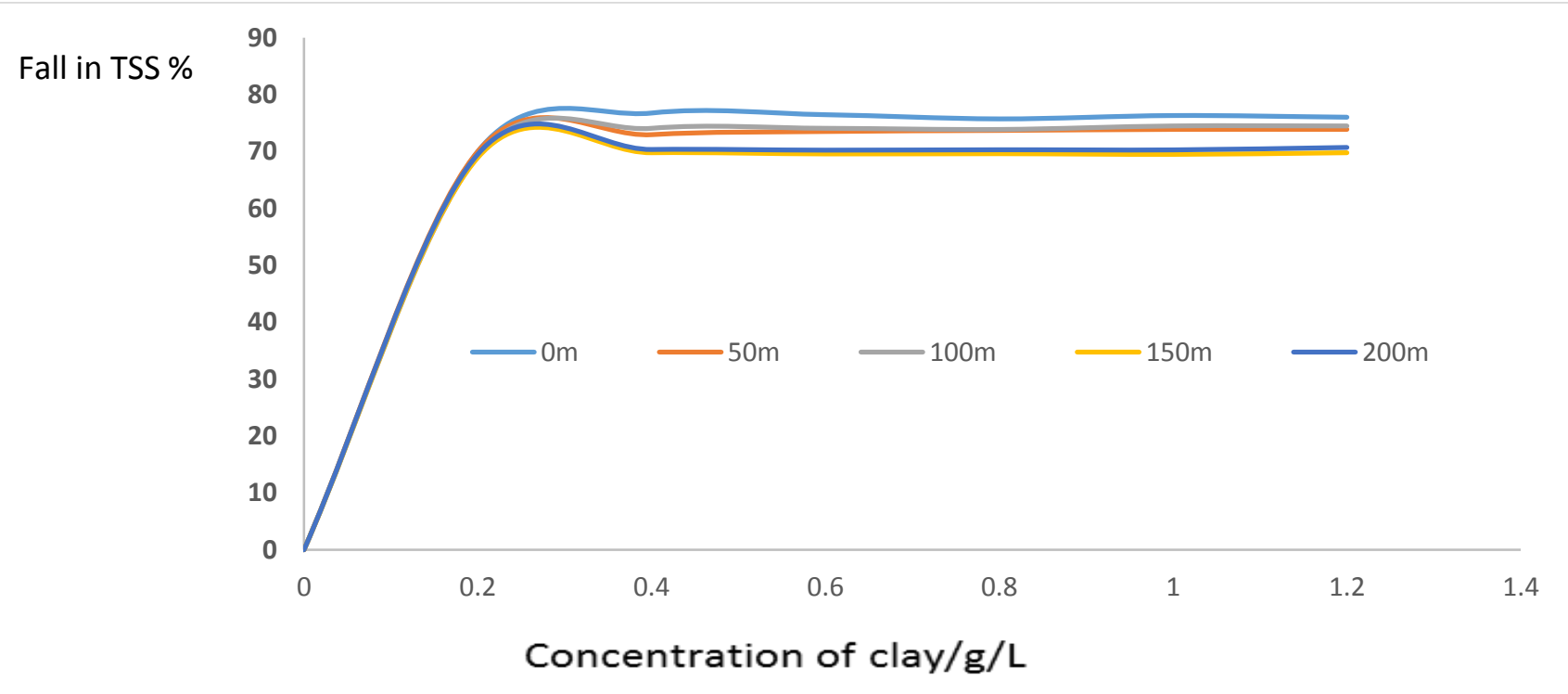

Figure 11a: Plot percentage fall in TSS versus clay concentration

Suspended solids in water can be living organisms, inorganic or organic solids and they tend to acquire electrostatic charges to keep suspended. Interactions between the partial charges on the suspended solids with the ion-dipoles on clay surfaces could have caused the particles to settle after being stirred with clay powder. 
Since edges and faces of clay particles readily adsorb anions, cations, and non-ionic and polar contaminants from natural water. The suspended solids accumulated on clay surface leading to their immobilization through the processes of ion exchange, coordination or ion-dipole interactions. It is also possible that suspended solids became held on surface of clay through $\mathrm{H}$-bonding, van der Waals interactions, or hydrophobic bonding arising from either strong or weak interactions. The strength of the interactions was dependent on structural and other features of the clay mineral. Presence of surface hydroxyl groups at the edges of clay lattices bonded to silicon, aluminium, or other octahedral cations, clays have high potential for adsorbing impurities in water. Hence Chelel clay readily removed solids from water. There was no observed influence on rate of removal of TSS to the location or point of sampling of water in the MB. Similarly, then initial concentration of TSS caused less significant influence on the rate of fall of TSS as concentration of clay increased probably because the coagulation and flocculation processes were highly favored during the clarification of MB water and the clay provided large enough number of sites to adsorb and neutralize charges on solids in the water tested.

Behavior of MB water resembled colloids suspended in water. Colloids could remain in suspension due to a number of processes. The deposition of the particles in MB water may have occurred through processes like surface filtration, size exclusion, bridging, and attachment. Cake or surface filtration occurred when particles with sizes larger than the pore size of the clay medium through which the MB water was filtered. Such particles were captured at the surface because particles were too large to pass through the pores (McDowell-Boyer et al. 1986). Depending on pore size and particle size distribution, larger particles were trapped in smaller pores; and this was due to the straining or size exclusion mechanism (Bradford and Torkzaban, 2008). It was also possible that suspended solids were removed through hydrodynamic bridging. Bridging may have occurred when several suspended particles arrived at a pore in clay mineral at the same time and wedged together (de Zwart, 2007). A bridge consisting of multiple particles was formed and thereby excluding dissolved and suspended solids from treated MB water to improve the quality. Particle bridging occurred under the influence of high rotation rate when $\mathrm{MB}$ water had mixed with clay because high velocities increased the probability that several particles entered the pores on clay at the same time (Ramachandran and Fogler, 1999). This was related to force balance between hydrodynamic forces and the repulsive particle-grain forces. At higher flow rates the hydrodynamic forces overcame the repulsive forces, thereby favoring bridging. Suspended solid deposition due to bridging was reported to depend on pore size distribution of the aquifer, the colloid size and concentration, and colloidgrain surface interaction forces (Ramachandran and Fogler, 1999), but this does not seem to hold when clay powder is added to polluted water because addition of clay beyond the optimum concentration of $0.4 \mathrm{~g} / \mathrm{L}$ did not yield significant changes in COD, TSS, TP, TN and even iron. So the bridging mechanism would take more impurities out of $\mathrm{MB}$ water because the ratio between the grain size and particle size was the most important parameters influencing bridging. Another aspect affecting bridging was the colloid concentration suspended in groundwater. Higher concentration increases the colloid flux and therefore leads to an increase of the likelihood of bridge formation (Sen and Khilar, 2006). It was reported that the most important parameters for bridging were particle concentration, flow velocity as higher flow velocity mobilized more particles and also overcome the repulsive particle-grain surface forces which would result in bridging, aspect ratio; the ratio between pore size and particle size influences the number of particles required to form a bridge. Small ratios are favorable for bridging, and properties of the colloid properties like shape, surface charge and roughness (Sen and Khilar, 2006). The when polluted water is vigorously stirred with clay powder, the concept of critical flux is introduced and linked to clay particle-impurity particle and impurity particle-clay surface interactions, so the particles of pollutants are captured on the walls between the micro channels in the clay lattice leading to the progressive formation of flocs. The complex interplay between multi-body surface interactions and hydrodynamics at nanometric scale leads to coagulation and flocculation observed experimentally in treatment of wastewater (Bacchin et al. 2011). Filtration removed the coagulated impurities and flocs paved way to overcoming pollutants in MB water. 


\section{Conclusions}

Fe-montmorillonite from Chelel at concentration of $0.4 \mathrm{~g} / \mathrm{L}$ optimally decreased COD by $78.1 \pm 0.21 \%$; TP by $44.6 \pm 1.63 \%$, Fe by $39.65 \pm 0.20 \%$. TN by $76 \pm 0.35 \%$ and TSS by $76.7 \pm 0.45 \%$ showing that the natural composite is good enough at removing most pollutants from water from $\mathrm{MB}$ at as low concentration as $0.4 \mathrm{~g} / \mathrm{L}$ of clay.

The relative percentages for removal of $\mathrm{Fe}$, and TP are lower than expected because the clay was already containing iron which affected its efficiency at removing iron and the phosphate.

Use of clay at concentrations higher than $0.4 \mathrm{~g} / \mathrm{L}$ yielded insignificant changes in $\mathrm{MB}$ water due to saturation or and competition.

\section{Recommendations}

More work needs to be done to establish the optimum working $\mathrm{pH}$ and temperature for the clay on MB waters.

There is need to establish whether acid or/and alkali leaching of the clay would enhance it water clarifying properties.

There is need to rule out possible interference of silicate ion in the phosphate analyses.

The management of the lake should be directed towards the reduction of nutrient input in the lake and reduction of sediment loading into the lake.

Sustainable farming methods should be encouraged to avoid influx of nutrients into the water bodies and impact on the quality of domestic water systems.

\section{Acknowledgement}

We are greatly indebted to Mr. Ruhara R. Budigi for the instruments used in analyzing the water.

\section{References}

1. Abd-Allah, SM.; Gaber, HM.; (2004) Monitoring of pesticide residues in different sources of drinking water in some rural areas. Alexandria J. Agric. Res. 49, 112-114.

2. Abdur R., Zafor M.A and Rahman M. (2013). Surface water quality and risk assessment in the vicinity of Sylhet City, International Journal of Water Resources and Environmental Engineering, Vol. 5(1), 29- 34

3. Akurut, M., Niwagaba, C. B., \& Willems, P. (2014a). Potential impacts of climate change on precipitation over Lake Victoria, East Africa, in the 21st Century. Water, 6 (Water Resources in a Variable and Changing Climate) (pp. 2634- 2659). doi:10.3390/w6092634.

4. Akurut, M., Willems, P., \& Niwagaba, C. B. (2014b). Assessing the influence of Lake Victoria flux on the Inner Murchison Bay water quality. In C. Brebbia (Ed.), Water Pollution XII, Algarve, Portugal (vol. 182, pp. 51-62). WIT Transactions on Ecology and The Environment, WIT Press. doi:10.2495

5. Akurut, M.: Niwagaba, C. B. Niwagaba \& Willems, P. (2017) Long-term variations of water quality in the Inner Murchison Bay, Lake Victoria Environ. Monit. Assess 189:22 DOI 10.1007/s10661-016-5730-4 
6. Ali, S. M., Khalid, A. R., \& Majid, R. M. (2014). The removal of Zinc, Chromium and Nickel from industrial waste water using Corn cobs ,55(1), $123-131$

7. Al-Jlil, S.A. and Alsewailem, F.D., (2009), Saudi Arabian Clays for Lead Removal in Wastewater. Applied Clay Science, 42, 671-674.

8. Aljlil, S.A., and Fares, D.A., 2014, Adsorption of copper and nickel on bentonite clay from wastewater. Athens Journal of Natural \& Formal Sciences, 1(1), 21-30

9. Al-Zahrani, A.A., Al-Shahrani, S.S., Al-Tawil, Y.A., (2000). Study on the activation of Saudi bentonite, part II: characterization of the produced active clay and its test as an adsorbing agent, J.King Saud Univ., 13, Eng. Sci. (2), 193-203.

10. American Public Health Association (1999). American Water Works Association, Water Environment Federation.

11. American Public Health Association (2003). Standard Methods for the Examination of water and Waste Water, 20th ed. Method $4500 \mathrm{E}$.

12. American Public Health Association (APHA), 1995. Standard Methods for Analysis of Water and Wastewater, $18^{\text {th }}$ edition. Port City Press, Baltimore,MD.

13. American Water Works Association, \& Water Enviroment Federation (1999). Standard Methods for the Examination of Water and Waste Water.

14. Ansari A.A., Gill S.S., Khan F.A. (2010) Eutrophication: Threat to Aquatic Ecosystems. In: Ansari A., Singh Gill S., Lanza G., Rast W. (eds) Eutrophication: causes, consequences and control. Springer, Dordrecht DOIhttps://doi.org/10.1007/978-90-481-9625-8_7

15. Bacchin, P; A. Marty; P. Duru; M. Meireles ; P. Aimar (2011). Colloidal surface interactions and membrane fouling: Investigations at pore scale Advances in Colloid and Interface Science 164, 2-11

16. Bracchini, L, Loiselle, S.A., Tognazzi, A., Dattilo, A.M., Focardi, S.,Cózar, A., (2007). The optical qualities of shallow wetland lined bays in Lake Victoria. Wetl Ecol Manag., 15, 509-519.

17. Bain, C.D. and Nadeau, P.H. (1986). Composition of some smectite and diagenetic illite clays

18. Banadda, E. N., Kansiime, F., Kigobe, M., Kizza, M., \& Nhapi, I. (2009). Landuse-based nonpoint source pollution: a threat to water quality in Murchison Bay, Uganda. Water Policy, 11, 93-104. doi:10.2166/wp.2009.106.

19. Barbooti, M., (2015), Simultaneous removal of chromium and lead from water by sorption on Iraqi Montmorillonite. Journal of Environmental Protection, 6, 237-249.

20. Bedelean, H., Maecaneanu, A., Burca, S., Stanca, M. (2010): Romanian zeolitic volcanic tuffs and bentonites used to remove ammonium ions from wastewaters. Hellenic J. Geosci. 45, 23-32

21. Bellir, K., Lehocine, M.B. and Meniai, A.-H., (2013): Zinc removal from aqueous solutions by adsorption onto bentonite. Desalination Water Treatment, 51, 5035-5048. 
22. Bhattacharyya, K.G. and S. Sen Gupta,S.(2008): Adsorption of a few heavy metals on natural and modified kaolinite and montmorillonite: a review, Advances in Colloid and Interface Science, 140(2). 114-131.

23. Bradford, S. \& Torkzaban, S. (2008). Colloid Transport and Retention in Unsaturated Porous Media: A Review of Interface-, Collector-, and Pore-Scale Processes and Models. Vadose Zone Journal. 7. 10.2136/vzj2007.0092.

24. Bwogi, A.L. (2012) Wetlands management http://www.mwe.go.ug/index.phb?option=com.content\&view=articleid=40\&itemid=201.

25. Cadena,F.; R. Rizvi, and R. W. Peters, (1990)."Feasibility studies for the removal of heavy metal from solution using tailoredbentonite, hazardous and industrial wastes," inProceedings ofthe 22nd MidAtlantic Industrial Waste Conference, pp. 77-94,Drexel University.

26. Chartterjee, T., Chartterjee, S., and HanWoo, S, (2009), Enhanced coagulation of bentonite particles in water by a modified chitosan biopolymer. Chemical engineering journal, 148, 414-419.

27. Chaterjee C, and Raziuddin M (2002). Determination of Water Quality Index (WQI) of a degraded river in Asanol Industrial Area, Raniganj.Burdwan, West Bengal. Nature, Environment and Pollution Technology. 1(2):181-189.

28. Christidis, G. E., Scott, P.W. and Marcopolous, T. (1995). Origin of bentonite deposits of Eastern Milos Islands, Greece:Geological, chemical and geochemical evidence. Clays and Clay Miner. 43(1), 63-77.

29. Christidis, G., Dunham, A. C. (1993). Composition variations in smectites of Milos Island, Greece. Clay Miner. 28, 255-257.

30. Cózar, A., Bergamino, N., Mazzuoli, S., Azza, N., Bracchini, L., Dattilo, A., et al. (2007). Relationships between wetland ecotones and inshore water quality in the Ugandan coast of Lake Victoria. Wetlands Ecology and Management, 15, 499- 507. doi:10.1007/s11273-007-9046-6.

31. de Zwart, A. H., de Boer, J., Vafei, A., Schotting R.J., Hassanizadeh, S.M. (2006). Experimental investigation of clogging processes in sandy aquifers near water supply wells, using X-ray chromatography. In preparation.

32. Dos Santos, V.C.G., Grassi, M.T., Abate, G. (2015): Sorption of Hg(II) by modified K10 montmorillonite: influence of $\mathrm{pH}$, ionic strength and the treatment with different cations. Geoderma 237-238, 129-136.

33. Egemen Ö (2000). Environment and water pollution. Ege University, Faculty of Fisheries. zmir, Turkey, (40): 120.

34. Gates, K. (2002). Mineralogy of bentonites. Clays and Clay Miner., 50:223-239.

35. Gikuma-Njuru, P., \& Hecky, R. (2005). Nutrient concentrations in Nyanza Gulf, Lake Victoria, Kenya: light limits algal demand and abundance. Hydrobiologia, 534(1-3), 131-140.

36. Gikuma-Njuru, P., Hecky, R., Guildford, S., \& MacIntyre, S. (2013): Spatial variability of nutrient concentrations, fluxes, and ecosystem metabolism in Nyanza Gulf and Rusinga Channel, Lake Victoria (East Africa). Limnology and Oceanography, 58(3), 774-789. 
37. Haande, S., Rohrlack, T., Semyalo, R. P., Brettum, P., Edvardsen, B., Lyche-Solheim, A. (2011). Phytoplankton dynamics and cyanobacterial dominance in Murchison Bay of Lake Victoria (Uganda) in relation to environmental conditions. Limnologica - Ecology and Management of Inland Waters, 41, 20 29. doi:10.1016/j.limno.2010.04.001. 22 Page 16 of 17 Environ Monit Assess (2017) 189:22

38. Hecky, R., Bugenyi, F., Ochumba, P., Talling, J., Mugidde, R., Gophen, M., (1994): Deoxygenation of the deep water of Lake Victoria, East Africa. Limnology and Oceanography, 39(6), 1476-1481.

39. Hecky, R., Mugidde, R., Ramlal, P., Talbot, M., \& Kling, G. (2010): Multiple stressors cause rapid ecosystem change in Lake Victoria. Freshwater Biology, 55(s1), 19-42.

40. Hecky, R.E. and Bugenyi, F.W.B. (1992): Hydrology and chemistry of the African great lakes and waterquality issues: problems and solutions. Mitt Int Ver Theor Angew Limnol 23:45-54

41. Hindawi Publishing Corporation (2011): Advances in application of natural clay and its composites in removal of biological, organic, and inorganic contaminants from drinking water Advances in Materials Science and Engineering Volume 2011, Article ID 872531,17pages doi:10.1155/2011/872531

42. implications for their origin. Clay and Clay Miner., 34(4) 455-464.

43. Inglezakis, V.J., Stylianou, M.A., Gkantzou, D., and Loizidou, M.D., (2007): Removal of Pb (II) from aqueous solutions by using clinoptilolite and bentonite as adsorbents. Desalination, 210, pp 248-256

44. Jepson, W. B., Browse, J. B. (1975): Composition of kaolinite, an electron microbe study. Clay and Clay Minerals 23, 316-317.

45. Jiang, J.Q., Zeng, Z., and Pearce, P., (2004): Evaluation of modified clay coagulant for sewage treatment. Chemosphere, 56, pp 181-185.

46. John Wiley and Sons Inc., (1993) Aquatic Pollution. E.A. Laws. 2nd ed. pp 148-149. New York

47. Kansiime, F., Nalubega, M., van Braggen, J. and Danny, P. (2003). The effect of wastewater discharge on biomass production and nutrient content of cyperus papyrus and Miscanthidium violacum in the Nakivubo wetland, Kampala Uganda. Water science and technology 48(5), 233-240

48. Kennedy, K.K., Maseka, K.J. and Mbulo, M. (2018): Selected adsorbents for removal of contaminants from wastewater: Towards engineering clay minearls. Open journal of applied sciences 8, 355-369 http://doi.org/10.4236/ojapps.2018.8807

49. Kerr, P. F. (1952). Formation and occurrence of clay minerals. Clays and Clay Minerals. 1, 19-32.

50. Kul, A.R., Koyuncu, H. (2010): Adsorption of $\mathrm{Pb}$ (II) ions from aqueous solution by native and activated bentonite: kinetic, equilibrium and thermodynamic study. J. Hazard. Mater. 179, 332-339

51. Lenore S. Clesceri, Andrew D. Eaton, Eugene W. Rice (2005). Standard Methods for Examination of Water \& Wastewater Method 5210B. Washington, DC: American Public Health Association, American Water Works Association, and the Water Environment Association. http://www.standardmethods.org

52. Luyiga, S., Haande, S., Semyalo, R. P., Kizito, Y. S., Miyingo-Kezimbira, A., Brettum, P., (2015). How water exchange and seasonality affect the eutrophication of Murchison Bay, Lake Victoria. Limnologica-Ecology and Management of Inland Waters, 53, 60-73. 
53. Lyddy-Meaney AJ, Ellis PS, Worsfold PJ, Butler Ecv and Mckelvie ID (2002). A compact flow injection analysis system for surface mapping of phosphate in marine waters. Talanta (58): 1043-1053.

54. Machiwa, P. K. (2003). Water quality management and sustainability: the experience of Lake Victoria Environmental Management Project (LVEMP)—Tanzania. Physics and Chemistry of the Earth, Parts A/B/C, 28(20), 1111-1115.

55. Mainstone C P and Parr. W (2002). Phosphorus in rivers - ecology and management. Sci. Tot. Environ., (282/283): 25-47.

56. Mavuti, K. M, M. R. Litterick, (1991). Composition, distribution and ecological role of zooplankton community in Lake Victoria, Kenyan waters. Verh. Interat. Verein. Limnol. 24: 1117-1122.

57. McDowell-Boyer, L.M.; R. Hunt, J.R.; Sitar, N. (1986) :Particle transport through porous media Water resources research 22(13) 1901-1921 https://doi.org/10.1029/WR022i013p01901

58. Mukasa-Tebandeke, I.Z., Ssebuwufu, P.J.M., Nyanzi, S.A., Schumann, A., Nyakairu, G.W.A., Ntale, M. and F. Lugolobi, (2015). The Elemental, Mineralogical, IR, DTA and XRD Analyses Characterized Clays and Clay Minerals of Central and Eastern Uganda. Advances in Materials Physics and Chemistry, 5, 67-86. http://dx.doi.org/10.4236/ampc.2015.52010

59. Murray, H. H. (2007): Applied Clay Mineralogy: Occurrences, Processing and Application of Kaolins, Bentonites, Palygorskite-Sepiolite, and Common Clays. Elsevier, Amsterdam

60. Musinguzi, M. Ejiri, A.H. (2016) Trends in degradation of freshwater urban wetlands in Kampala Uganda a case study of Lubigi wetland. International journal of research in earth and environmental sciences4(3) http://www.ijsk.org/ijrees.html

61. Ramachandran V, Fogler HS. (1999). Plugging by hydrodynamic bridging during flow of stable colloidal particles within cylindrical pores J Fluid Mech 385., 129-156. https://doi.org/10.1017/S0022112098004121

62. Razman A R, Tajudin M H, Ooi L H and Tang M.K (1999). Fertilizer Requirement and Practical of The Plantation Industry in Malaysis,Felda Agricultural Services.

63. Rozic, M., Stefanovic, S.C., Kurajica, S., Vancina, V., and Hodzig, E. (2000): Ammoniacal nitrogen removal from water by treatment with clays and zeolites. Water Res. 34, 3675-3681.

64. Sajidu,S.M.I. Pearson, I., Masamba, W.R.L., Henry, E.M.T., and Kayambazinthu, D. (2006). Removal of Cd(II), $\mathrm{Cr}(\mathrm{III}), \mathrm{Cu}$ (II), $\mathrm{Hg}$ (II), $\mathrm{Pb}$ (II) and $\mathrm{Zn}$ (II) cations frm Tundulu from auoues solution by mixed clay from Tundulu in Malawi and characterization of the clay. Water SA 32(4) 519-526.

65. Scheren, P., Zanting, H., \& Lemmens, A. (2000). Estimation of water pollution sources in Lake Victoria, East Africa: application and elaboration of the rapid assessment methodology. Journal of Environmental Management, 58(4), 235-248.

66. Sen, T. K., and Khilar, K. C. (2006). Review on subsurface colloids and colloid-associated contaminant transport in saturated porous media. Advances in Colloid and Interface Science, 119(2-3), 71-96.

67. Singh, N., Nagpal, G., Agrawal, S. and Rachina (2018). Water purification by using various adsorbents: A review. Environmental technology and innovation 11, 187-240. http://doi.org/10.1616/j.eti.2018.05.006. 
68. Smith, V.H., Tilman, G.D., and Nekola, J.C. (1999). Eutrophication: Impacts of excess nutrient inputs on freshwater, marine, and terrestrial ecosystems. Environ. Pollut. 100: 179-196.

69. Srinivasan, R.. (2011): Advances in application of natural clay and its composites in removal of biological, organic, and inorganic contaminants from drinking water. Advances in Materials Science and Engineering, 11, 1-17.

70. Ssebiyonga, N., Erga, S. R., Hamre, B., Stamnes, J. J., \& Frette, Ø. (2013). Light conditions and photosynthetic efficiency of phytoplankton in Murchison Bay, Lake Victoria, Uganda. LimnologicaEcology and Management of Inland Waters, 43(3), 185-193.

71. Swamy A.; Terer Erick Kipngetich, Magut Hillary and T. (2013) CODEN (USA): IJPLCP ISSN: 0976-7126 Int. J. of Pharm. \& Life Sci. (IJPLS), 4(7), 2828-2833 2829

72. Syafalni, Rohana Abdullah, Ismail Abustan, Aimi Nadiah Mohd Ibrahim (2013). Wastewater treatment using bentonite, the combinations of bentonite-zeolite, bentonite-alum, and bentonitelimestone as adsorbent and coagulant International Journal of Environmental Sciences Volume 4 No.3, 2013391

73. Tahir, S.S., and Rauf, N., (2004) Removal of Fe (II) from the wastewater of a galvanized pipe manufacturing industry by adsorption onto bentonite clay. Journal of engineering management, 73, pp 285-292.

74. Tamatamah, R. A., Hecky, R. E., \& Duthie, H. (2005). The atmospheric deposition of phosphorus in Lake Victoria (East Africa). Biogeochemistry, 73, 325-344. doi:10.1007/s10533-004-0196-9. USDA (2015). USDA. http://www.pecad.fas.usda. gov/lakes/images/lake0314.TPJO.2.txt. Accessed 12 May 2015.

75. Tanabe, K.(1981)."Solid acid and base catalysis," in Catalysis-Science and Technology, J. R. Anderson and M. Boudart, Eds.,p. 231, Springer, New York, NY, USA.

76. U.S. Environmental Protection Agency, Eutrophication: http://www.epa.gov/maia/html/eutroph.html

77. U.S. Environmental Protection Agency, National Nutrient Guidance: http://www.epa.gov/ost/criteria/nutrient/guidance/

78. van Olphen, H. (1977),An Introduction to Clay Colloid Chemistry,Wiley Interscience, New York, NY, USA, 2nd edition, 1977.

79. Volzone, C., Foletto, F.L. and Porto, L.M. (2003). Performance of an Argentinian acid-activated bentonite in the bleaching of soybean oil. Braz. J. Chem. Eng. 20(2) 123-126.

80. World Health Organization, WHO (2004). Guidelines for Drinking Water Quality, vol. 1, 3 rd ed. World Health Organization, Geneva, Switzerland.

81. World Health Organization, WHO (2008). Guidelines for Drinking Water Quality, Incorporating the first and second Addenda. vol. 1, 3rd ed. World Health Organization, Geneva, Switzerland. 20. Oeteman, B.C.J (1980). 
82. Yarahmadi, M., Hossieni, M., Bina, B., Mahmoudian, M.H., Naimabadie, A., and Shahsavani, A., (2009), Application of Moringa Oleifer Seed Extract and Polyaluminium Chloride in Water Treatment. World applied sciences journal, 7 (8), pp 962-967.

83. Zadaka, D., Nir, S., Radian, A. and Mishael, Y. G., (2009), Atrazine removal from water by poly cation-clay composites: effect of dissolved organic matter and comparison to activated carbon. Water Research, 43(3), 677-683.

84. Zamparas, M., Drosos, M., Geogiou, Y., Deligiannakis, Y., Zacharias, I. (2013): A novel bentonite-humic acid composite material Bephos ${ }^{\mathrm{TM}}$ for removal of phosphate and ammonium from eutrophic waters. Chem. Eng. J. 225, 43-51.

85. Zhang, J. and Chi, J. (2002) Automated Analysis of Nanomolar Concentrations of Phosphate in Natural Waters with Liquid Waveguide Environ. Sci. Technol., 36 (5), 1048-1053 DOI: 10.1021/es011094v

86. Zhang, X. and Wang, X. (2015) Adsorption and Desorption of Nickel (II) Ions from Aqueous Solution by a Lignocellulose/Montmorillonite Nanocomposite. PLoS One, 10, e0117077. https://doi.org/10.1371/journal.pone.0117077

87. Zhang, X., Lv, G., Liao, L., He, M., Li, Z., Wang, M. (2012): Removal of low concentrations of ammonium and humic acid from simulated groundwater by vermiculite/palygorskite mixture. Water Environ. Res. 84, 682-688.

88. Zhao, Y., Yang, Y., Yang, S., Wang, Q., Feng, C., Zhang, Z. (2013): Adsorption of high ammonium nitrogen from wastewater using a novel ceramic adsorbent and the evaluation of the ammonium-adsorbedceramic as fertilizer. J. Colloid Interface Sci. 393, 264-270.

89. Zhu, J., Cozzolino, V., Pigna,M.; Huang, Q.; Caporale, A.G. and Violante, A. (2011). Sorption of Cu, Pb and $\mathrm{Cr}$ on Na-montmorillonite: Competition and effect of major elements. Chemosphere, 84:484-489 